\title{
The Quality Effect: \\ Does Financial Liberalization Improve the Allocation of Capital?
}

Abdul Abiad, Nienke Oomes, and

Kenichi Ueda 


\title{
IMF Working Paper
}

\author{
Research Department
}

\section{The Quality Effect: Does Financial Liberalization Improve the Allocation of Capital?}

\author{
Prepared by Abdul Abiad, Nienke Oomes, and Kenichi Ueda ${ }^{1}$ \\ Authorized for distribution by Ashoka Mody
}

June 2004

\begin{abstract}

\section{This Working Paper should not be reported as representing the views of the IMF.} The views expressed in this Working Paper are those of the author(s) and do not necessarily represent those of the IMF or IMF policy. Working Papers describe research in progress by the author(s) and are published to elicit comments and to further debate.
\end{abstract}

The study documents evidence of a "quality effect" of financial liberalization on allocative efficiency, which is measured by the dispersion in Tobin's Q across firms. Based on a simple model, the authors predict that financial liberalization, by equalizing access to credit, reduces the variation in expected marginal returns. They test this prediction using a new financial liberalization index and firm-level data for five emerging markets: India, Jordan, Korea, Malaysia, and Thailand. They find strong evidence that financial liberalization, rather than financial deepening, improves allocative efficiency.

JEL Classification Numbers: D61, E44, G14, G18, O16

Keywords: Tobin's Q, financial liberalization, investment, allocative efficiency, inequality

Author's E-Mail Address: aabiad@,imf.org; noomes@,imf.org; kueda@imf.org

\footnotetext{
${ }^{1}$ We would like to thank Xavier Gine, Aart Kraay, Inessa Love, Ashoka Mody, Robert Townsend, and other participants in the IMF and World Bank seminars for helpful comments and suggestions. The usual caveats apply.
} 


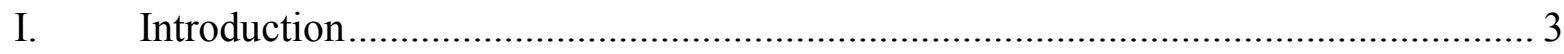

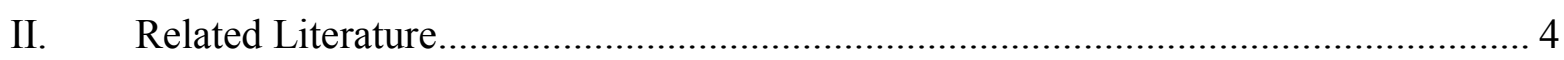

A. Studies on Quantity Effects ..................................................................... 4

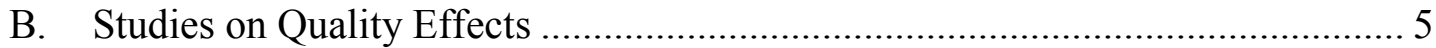

C. Studies on Financial Deepening............................................................. 6

III. The Model .................................................................................................... 7

IV. Dispersion in Tobin's Q as a Measure of Allocative Efficiency ............................. 9

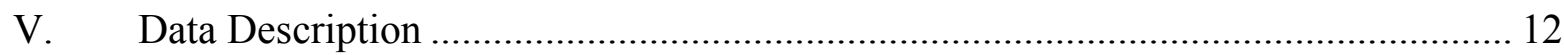

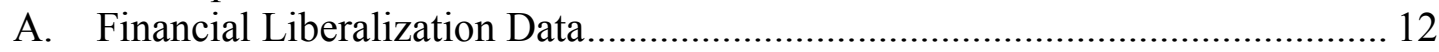

B. Corporate Finance Data ...................................................................... 13

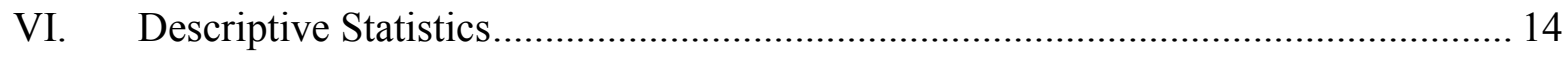

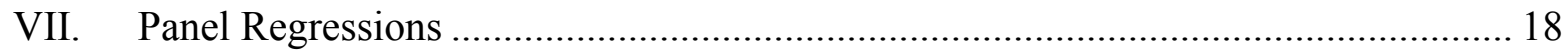

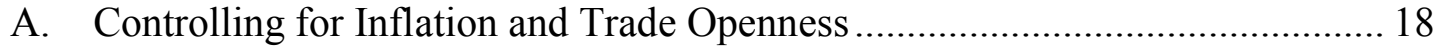

B. Controlling for Financial Deepening ......................................................... 20

C. Controlling for Persistence and Endogeneity ............................................ 23

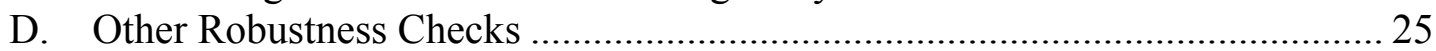

VIII. Conclusion .......................................................................................... 26

Appendix

I. Measuring Dispersion in Q: Four Inequality Indices....................................... 28

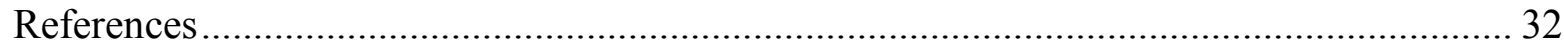

Tables

1. International Finance Corporation (IFC) Corporate Financial Database Coverage .. 14

2. Fixed-Effects and Random Effects ............................................................. 20

3. Fixed-Effects Regressions with Financial Development Indicators ....................... 21

4. Arellano-Bond Dynamic Panel Regressions.................................................. 24

Appendix Table

5. Coding of Financial Reforms in the Five Countries ........................................... 29

Figures

1. Dispersion Measures, Pre- and Post-Liberalization ............................................. 16

2. Five Countries: Timplots of Financial Liberalization and Q Dispersion.................. 17 


\section{INTRODUCTION}

The rationale for financial liberalization has been based on two potential benefits: a quantity effect, manifested in higher levels of savings and investment in an economy, and a quality effect, manifested in a more efficient allocation of capital. Although a growing body of literature finds little evidence of a quantity effect, this paper reports evidence of a quality effect.

Previous research on this subject has been constrained by the problem of how to measure efficiency in allocating capital. One of the main contributions of this paper is that it proposes a new measure of allocative efficiency, based on the variation in expected returns to investment across firms. We show, in a simple model, that if liberalization is truly efficiency-enhancing, this variation should be lower in countries with more liberalized financial sectors, where markets determine the allocation of credit, and should be higher in countries with less liberalized financial sectors, where the allocation of credit is determined by governments. Intuitively, the removal of government controls implies that credit will be reallocated from firms with low expected returns to investment in firms with high expected returns, raising expected returns for the former and reducing them for the latter. We measure the variation in expected returns by the dispersion in Tobin's Q in a given country and year, controlling for industry and age effects, using 413 firms in five emerging market economies - India, Jordan, Korea, Malaysia, and Thailand-from 1980 to 1994.

Another important contribution of this paper is the distinction, not often made in the literature, between financial liberalization and financial deepening. Financial liberalization, on the one hand, refers to a reduction in the role of government, and an increase in the role of the market, in allocating credit. We measure this using a new financial-liberalization index, which takes into account credit controls, interest rate controls, entry barriers for banks, regulations, privatization, and restrictions on international financial transactions. Financial deepening, on the other hand, refers to an increase in the volume of credit being intermediated in financial markets, and is typically measured by indicators such as M2, credit to the private sector, or stock market capitalization relative to GDP. ${ }^{2}$ Although the two will tend to be related, they are not equivalent. ${ }^{3}$ Financial deepening affects access to finance, while liberalization affects the incentives with which credit is deployed. We investigate the role each factor plays in allocative efficiency.

\footnotetext{
${ }^{2}$ It is unfortunate that many recent studies have used the term "financial development" when referring specifically to financial deepening. Financial development should be thought of as a much broader concept reflecting improvements in the functioning of the financial sector. These include increased access to financial intermediation, greater diversification opportunities, improved information quality, and better incentives for prudent lending and monitoring.

${ }^{3}$ For example, during the 1970s and up into the early 1980s, Japan and France had financially deep markets that were highly repressed. Conversely, Great Britain in the late 1970s and several Latin American countries, including Peru, Argentina, and Brazil, in the 1990s had liberalized financial markets that were relatively shallow.
} 
Our main result is that financial liberalization improves the allocation of capital, thus providing an affirmative answer to the question posed in the title of this paper. We present two types of evidence in favor of this claim. First, we present descriptive statistics that show that the dispersion in Tobin's Q decreased in all of the five countries in our sample following financial liberalization. Second, we run several panel regressions of dispersion in $\mathrm{Q}$ on financial liberalization and show that the coefficient on financial liberalization is strongly negative, even after controlling for omitted variables, time trends, endogeneity, and other factors.

We have three additional findings. First, financial liberalization appears to be more important than financial deepening for improving allocative efficiency; in fact, once financial liberalization is controlled for, increased bank credit is associated with lower allocative efficiency. This might reflect potential misallocations of credit during lending booms. Second, stock market liquidity (as measured by stock market turnover relative to market capitalization) does lower the dispersion of marginal returns, and this effect remains even after controlling for financial liberalization. This could reflect either an independent effect of stock market liquidity on allocative efficiency or an increase in the accuracy of stock market valuation as stock markets become more liquid. Third, we observe in several countries that the dispersion in Q seems to have increased gradually prior to liberalization. This suggests that credit allocation in these countries worsened over time, as credit continued to be directed toward firms that were already above their optimal sizes, which continued to deprive those that needed it most.

The paper is organized as follows. Section II reviews the literature on the quantity effects and quality effects of financial liberalization, as well as the related literature on financial deepening. Section III then presents a simple model that shows how government intervention in credit allocation generates variation in the rates of return to investment for firms that are otherwise identical in their production function, adjustment cost function, and real wage costs. Section IV explains our rationale for using the dispersion in $\mathrm{Q}$ as our measure of variation in expected marginal returns. Data sources and details on our new financial liberalization index are discussed in Section V. The descriptive statistics and regression results are presented in Sections VI and VII, respectively. Section VIII concludes by summarizing our findings.

\section{RELATED LITERATURE}

\section{A. Studies on Quantity Effects}

Much of the literature on financial liberalization has focused on the question of whether it has a positive "quantity effect," manifested in higher levels of savings and investment. One theoretical argument in favor of such a quantity effect, going back to McKinnon (1973) and Shaw (1973), is that higher interest rates that follow the removal of interest rate ceilings will generate higher savings, and in turn, higher investment. Higher rates of return may also result from better insurance against future risk, which as Obstfeld (1994) argues may induce a shift toward higherrisk-higher-return projects. Finally, a positive quantity effect on investment may be expected because increased competition between banks can lead firms to internalize external effects in investment (Ueda, 2000). 
However, there are also reasons to expect a negative, or at least ambiguous, quantity effect of financial liberalization. First, even if rates of return increase with improved risk-sharing or following the removal of interest rate ceilings, the effect on savings and investment will depend on whether income or substitution effects prevail. Second, even if liberalized financial sectors provide for better insurance against future risk, this may in fact lower the incentive to save for future needs (Devereux and Smith, 1994). ${ }^{4}$ That is, financial liberalization can create a better functioning financial sector without necessarily increasing savings and investment.

Since the direction of the quantity effect is thus theoretically ambiguous, it is perhaps not surprising that empirical studies find mixed, and occasionally even negative, effects of liberalization on savings and investment. Using both a cointegration and an augmented Euler equation approach, Bandiera and others (2000) show that, in a sample of eight developing countries, financial liberalization is not associated with an increase in savings. In fact, certain aspects of liberalization - those that reduce liquidity constraints for household consumption — are associated with a fall in savings. Several country studies corroborate these findings. For example, Jayaratne and Strahan (1996) find that the deregulation of bank branches in the United States in the 1970s did not increase the volume of bank lending, and Sancak (2002) finds that the 1980 financial reforms in Turkey did not lead to a reduction in financing constraints.

\section{B. Studies on Quality Effects}

Given the theoretically ambiguous direction of the quantity effect, we cannot evaluate the success of liberalization by assessing whether it has a positive or negative effect on savings and investment. Instead, we propose to judge the merits of liberalization by its "quality effect," that is, by assessing whether it improves the allocation of capital across firms.

Thus far, only a few studies have attempted to estimate quality effects, and they have generally found positive results. In an early study, Cho (1988) finds that financial liberalization in Korea led to a decrease in the variation in borrowing costs, which he interprets as an improvement in allocative efficiency. In a more recent study, Galindo, Schiantarelli, and Weiss (2002) also report a positive and significant effect of liberalization on a measure of allocative efficiency, using firm-level data for 12 developing countries. Finally, in a somewhat different context, Chari and Henry (2003) find that capital account liberalization (rather than financial liberalization) improves the allocation of capital across (rather than within) countries.

In our view, the main problem with existing studies on quality effects has been their definition of allocative efficiency. For example, Cho (1988)'s definition of allocative efficiency as a reduction in the variation in borrowing costs is almost tautological, as this variation naturally decreases when governments eliminate directed credit and interest rate controls. Moreover, even if all firms faced identical borrowing costs, the allocation of capital would still not be efficient if access to credit were determined by noneconomic factors. Galindo and others (2002) use a more sophisticated definition and argue that, if capital is allocated more efficiently after financial

\footnotetext{
${ }^{4}$ Without a change in international financing constraints, these lower savings would also need to be accompanied by lower investment.
} 
liberalization, more capital should flow to firms with a higher marginal productivity of capital. They test this hypothesis by assessing whether an investment-weighted average of ex post marginal returns increases relative to a naïve size-weighted average of ex post marginal returns. ${ }^{5}$ However, a problem with this definition is that, as they themselves note, "the marginal product of capital of a perfectly efficient economy would be the same in all firms. Consequently, random allocations of capital would do as well as any other allocation" (p. 12). In other words, in a perfectly efficient economy, the investment-weighted average should be equal to the sizeweighted average. But this implies that the ratio of investment-weighted to size-weighted average ex post marginal returns should converge to one, not increase away from one, which is the case for several countries in their sample.

\section{Studies on Financial Deepening}

Although this paper focuses on financial liberalization, our study is obviously closely related to the literature on financial deepening, in the context of which quantity and quality effects can also be discussed. The seminal papers in this literature are those by King and Levine (1993) and Levine, Loayza, and Beck (2000), whose regression results suggest a positive effect of financial deepening (measured by M2 and the ratio of private credit to GDP) on subsequent economic growth. However, as Townsend and Ueda (2003) point out, it may not be valid to assume a stationary relationship between financial deepening and economic growth, because growth theories (e.g., Greenwood and Jovanovic, 1990, and Acemoglu and Zilibotti 1997) suggest that financial deepening is a transitional phenomenon in the move toward a steady state.

Recent studies have used alternative approaches to study the effects of financial deepening. In an important cross-country study, Rajan and Zingales (1998) find that industries that are more dependent on external finance grow more slowly than other industries in countries with less developed financial markets (whether measured by financial depth, or improved accounting standards). In another well-known study, Wurgler (2000) finds that in countries with deeper financial sectors, capital is better allocated in the sense that it tends to flow to growing industries. ${ }^{6}$ Beck, Levine, and Loayza (2000) find that financial deepening affects GDP growth through increases in total factor productivity, rather than through factor accumulation. Finally, Love (2001) finds that financial deepening is associated with a drop in the sensitivity of investment to the availability of internal funds, which can be interpreted as a proxy for financing constraints.

\footnotetext{
${ }^{5}$ They proxy ex post marginal returns by the sales-to-capital ratio and the operating-profits-tocapital ratio, under the assumption of a constant-returns-to-scale technology.

${ }^{6}$ In our view, this is not necessarily evidence of a quality effect, since governments can artificially stimulate growth in certain industries using directed credit and differential interest rates. For example, while Japan is one of the most important examples in Wurgler's study, the Japanese government is known to have substantially intervened in allocating capital among firms (see, e.g., Ito, Okuno, Kiyono, and Suzumura, 1988).
} 
But is it really financial deepening that has led to the positive outcomes noted in these studies? Or might it be financial liberalization - which is distinct from, but correlated with, financial depth - that matters? None of these studies controlled for financial liberalization, mainly due to the absence of an adequate measure. In recent years, however, time-varying, cross-country measures of financial liberalization have been developed by Abiad and Mody (2003), Kaminsky and Schmukler (2003), and Edison and Warnock (2003). Given the importance of this distinction for policy prescriptions, we explicitly control for both financial liberalization and financial deepening in our panel regressions. Our results suggest that it is financial liberalization, rather than financial deepening, that improves allocative efficiency.

\section{THE MODEL}

In this section we present a simple model to show that the distribution of marginal returns to capital across firms becomes more equal (i.e., the allocation of capital becomes more efficient) as financial sectors become more liberalized.

We incorporate the classical Marshallian view that each firm, depending on the industry to which it belongs, has an optimal operating size. We thus write the profit function for a firm at time $t$ as follows:

$$
\pi\left(K_{t}, L_{t}\right)=f\left(K_{t}, L_{t}\right)-w L_{t}-\phi\left(I_{t}\right)-R K_{t}
$$

with a standard law of motion for capital:

$$
K_{t}=(1-\delta) K_{t-1}+I_{t}
$$

where $K$ denotes capital, $L$ denotes labor, $w$ is the real market wage, $I$ is investment, and $R$ is the gross interest rate. The function $f$ is a constant-returns-to-scale (CRS) production function with partial derivatives $f_{1}>0, f_{2}>0, f_{11}<0, f_{22}<0$, and $f_{12}>0$. The function $\phi\left(I_{t}\right)$ measures the adjustment cost of investment, and satisfies $\phi^{\prime}>0$ and $\phi^{\prime \prime}>0 .^{7}$

Profit maximization gives us the unique steady state optimal policy $\left(K^{*}, I^{*}, L^{*}\right)$, which satisfies

$$
\begin{aligned}
& f_{1}\left(K^{*}, L^{*}\right)-\phi^{\prime}\left(I^{*}\right)=R, \\
& f_{2}\left(K^{*}, L^{*}\right)=w,
\end{aligned}
$$

and

$$
\delta K^{*}=I^{*}
$$

Since the production function is CRS, the labor market condition (4) determines the capital-tolabor ratio, given the real wage $w$. By substituting $L^{*}$ in (3) by implicit function of $K^{*}$ using (4),

${ }^{7}$ Allowing for the presence of small fixed adjustment costs would not change the results. 
and substituting $I^{*}$ by (5), the capital market condition (3) becomes a function of $K^{*}$ only. This determines $K^{*}$, which is unique because the production function is concave while the adjustment cost function is convex. Similarly, the transition path of $(K, L)$ to the steady state is uniquely determined. ${ }^{8}$

In a fully liberalized financial sector, each firm faces the same market interest rate $R$, and can invest as much as it wants. This implies that the marginal returns to capital, given by (3), are equal across firms. In a non-liberalized financial sector, however, governments may impose price controls (e.g., interest rate floors or ceilings) or quantity controls (e.g., directed credit). As we will show below, this generates variation in the marginal returns to capital across firms.

As an example of price controls, consider the case where governments control interest rates, and apply different rates to different firms. In this case, each firm will still equate its marginal return to capital to its interest rate, but firms facing higher interest rates will need to set a lower steadystate level of capital $K^{*}$, implying a higher marginal return to capital. In other words, variation in interest rates across firms generates variation in returns across firms.

As an example of quantity controls, consider the case where interest rates are equal, but the investment amount $I$ is determined by the government - either directly, via control of firms' investment plans, or indirectly, via credit allocation. Let us denote this amount by $\hat{I}$. In this case, firms maximize their profit function (1) subject to (2) and the additional constraint $I=\hat{I}$. Letting $\lambda$ denote the Lagrange multiplier associated with this constraint, the capital market condition can then be rewritten as

$$
f_{1}\left(K^{* *}, L^{* *}\right)-\phi^{\prime}(\widehat{I})=R+\lambda
$$

If firms are constrained with respect to the amount they can invest $\left(\hat{I}<I^{*}\right), \lambda$ is positive, implying that the marginal return to capital — the right hand side of equation ( $\left.3^{\prime}\right)$ - -is higher than the market-based interest rate $R$. Conversely, if firms are forced to overinvest $\left(\hat{I}>I^{*}\right)$, as may happen, for example, when governments identify specific industries for development or employment objectives, $\lambda$ becomes negative. This implies that the marginal return to capital is lower than the market-based interest rate. ${ }^{9}$

The above analysis shows that when a government controls a financial sector, either by price controls or quantity controls, this generates variation in marginal returns across firms that face

\footnotetext{
${ }^{8}$ We do assume that these adjustments are quick — that is, can be completed within a year-so that the steady-state values can be approximated with annual data.

${ }^{9}$ In the case of a uniform and binding interest rate ceiling that prevents supply from matching demand, so that banks ration credit based on noneconomic factors, the same analysis as for quantity controls applies: firms that can get credit will have low marginal returns, while those that are credit constrained will have high marginal returns.
} 
the same production function, adjustment cost function, and real wage costs. When such controls are eliminated, credit will be reallocated from firms with low marginal returns (i.e., the overinvesting firms) to firms with high marginal returns (i.e., the under-investing firms). We thus predict that, as financial markets become more liberalized, capital is allocated more efficiently, which is reflected in a more equal distribution of marginal returns to capital. ${ }^{10}$

\section{Dispersion in Tobin's Q as a Measure of Allocative Efficiency}

When we generalize the above analysis to the stochastic case, where the real wage, the interest rate, and productivity are allowed to vary over time, our predictions apply to the ex-ante, expected marginal returns to capital, rather than the ex-post, realized marginal returns. We cannot use ex-post marginal returns to test the hypothesis that financial liberalization leads to a more equal distribution of returns, because the dispersion in ex-post marginal returns may actually increase after liberalization, if a better financial system leads firms to select higher-risk and higher-return projects (Obstfeld, 1994).

A good measure of expected marginal returns to capital is Tobin's Q, which measures the market value of a firm's securities relative to the replacement cost of its assets. ${ }^{11}$ More precisely, the numerator of Tobin's Q is the sum of the market value of its equity (its stock market capitalization) and the market value of its debt (its current and long-term liabilities). The denominator of Tobin's Q is the replacement costs of all tangible assets (property, plant, and equipment) and non-tangible assets (e.g., technical expertise, trademarks, and patents). We can thus regard Tobin's Q as essentially the discounted sum of expected future profits per asset. It should equal unity in perfectly functioning markets and in the absence of measurement errors. ${ }^{12}$

${ }^{10}$ This prediction would still follow from a more complicated model, such as the model by Hellman and others (1996), in which government control of the financial sector can be beneficial if it induces banks to lend more than they would in the presence of informational constraints. More generally, moral hazard or limited liability could generate dispersion in Tobin's Q across firms as the optimal allocation (this could be shown, for example, in a model similar to Phelan, 1995). Even in such cases, however, the variation in marginal returns would still reflect an inefficient allocation of capital, to the extent that governments allocate capital based on concerns other than its marginal productivity.

${ }^{11}$ We initially assume, for simplicity, that the stock market valuation of firms is efficient in that it correctly reflects discounted future expected profits. However, as Morck and others (2000) suggest, the efficiency of stock market valuation itself may improve with financial liberalization. In this case, an observed decline of dispersion in Tobin's Q could potentially be attributed solely to the improvement in stock market valuation. In order to distinguish between the effects of better valuation and better allocation, we explicitly control for stock market development (both capitalization and turnover) in Section VII, and show that the positive effect of liberalization on allocative efficiency remains.

12 If the market valuation per unit of capital is higher than the replacement cost of a unit of capital, firms have an incentive to invest by issuing equity, leading to a fall in marginal returns and hence in market valuation per unit. Similarly, if the market value of a unit of capital is lower 
In practice, Tobin's $\mathrm{Q}$ can differ from unity due to, inter alia, measurement error and financial constraints.

The limitations of our dataset, described in the next section, necessitate us to estimate Q by making four approximations that are common in the literature. First, since data on non-tangible assets are not available, we follow the convention to use only tangible assets in the denominator (e.g., Blanchard, Rhee, and Summers, 1993; Bond and Cummins, 2001; Chari and Henry, 2003). Second, since we do not have data on the market value of debt, we use the book value of debt instead. ${ }^{13}$ Third, in the absence of data on the replacement cost of tangible assets, we approximate replacement costs by adjusting book values for cumulative inflation. ${ }^{14}$ Fourth, we use average $\mathrm{Q}$ as a proxy for marginal $\mathrm{Q}$, even though marginal $\mathrm{Q}$, the ratio of the increment of market valuation to the cost of the associated investment, provides the best estimate of the expected marginal return to capital (Hayashi, 1982).

While these four approximations create measurement errors, these errors mainly affect the estimated level of Q, and have a much smaller effect on the dispersion of Q. Nevertheless, we attempt to correct for potential measurement errors by adjusting our estimates of $Q$ for industry and age effects. We adjust for industry effects in order to correct for the disparity between marginal and average $\mathrm{Q}$ that can arise from industry-specific production functions or adjustment cost functions. ${ }^{15}$ In addition, controlling for industry effects allows us to correct for differences in Tobin's Q due to differences in wages across industries. We adjust for differences in the age of firms in order to correct for the fact that firms of different ages have different vintages of

than its replacement cost, firms have an incentive to disinvest, leading to an increase in marginal returns, and hence an increase in market value. Only when $Q$ equals one, firms have neither an incentive to invest nor to disinvest. Also, investment firms looking for M\&A would arbitrage if there is discrepancy between the replacement cost of assets and the market valuation for a firm.

${ }^{13}$ While there is a standard approach to convert book values of debt to market values (Blanchard, Rhee, and Summers, 1993), this cannot be applied in our case because data on corporate bond rates are not available for the relevant time period. According to Chari and Henry (2003), estimating the market value of debt would require further assumptions about unobservable corporate bond rates, which may be a cure worse than the ailment.

${ }^{14}$ Specifically, if $K_{t}$ is the reported value of tangible assets in year $t$, the inflation-adjusted value of tangible assets is given by $\left(K_{t}-(1-\delta) \cdot \mathrm{K}_{\mathrm{t}-1}\right)+(1-\delta) \cdot \mathrm{K}_{\mathrm{t}-1} \cdot\left(1+\pi_{\mathrm{t}}\right)=K_{t}+(1-\delta) \cdot \mathrm{K}_{\mathrm{t}-1} \cdot\left(1+\pi_{\mathrm{t}}\right)$, where $\delta=0.05$ is an assumed depreciation rate and $\pi_{t}$ is the inflation rate. Note that all our results continue to hold even if we do not adjust for inflation.

${ }^{15}$ We ignore possible differences arising from patent holdings, because most blueprints are produced by firms in industrial countries, while we focus on developing countries. 
machines and factories. In addition, controlling for age effects allows us to correct for the fact that younger firms may not yet be correctly valued in the stock market. ${ }^{16}$

In order to control for industry and age effects, we run the following regression for each country and year:

$$
q_{i}=\alpha+\beta \cdot \operatorname{Age}_{i}+\sum_{j=1}^{J} \gamma_{j} \cdot \operatorname{Industry}_{i j}+\varepsilon_{i}
$$

where $q_{i}$ is the logarithm of Q for firm $i,{ }^{17} A g e_{i}$ is the difference between the current year and the year of establishment of firm $i$, and other controls are latent variables. ${ }^{18}$ Running this regression gives us a residual $e_{i}$ that captures the component of $q_{i}$ that is unexplained by the fixed effects of age and industry. Using this estimate, we then construct an adjusted measure of Q:

$$
\hat{q}_{i}=\operatorname{mean}(q)+e_{i}=\left(\frac{1}{n} \sum_{k=1}^{n} q_{k}\right)+e_{i} .
$$

Finally, we calculate the dispersion in $\hat{q}_{i}$ by using four standard inequality measures. These four measures are (1) the Gini coefficient, (2) the mean logarithm of deviations, (3) the Theil index, and (4) the coefficient of variation. A comparison between these four indices is useful, because they all have different sensitivities to different ranges of the distribution. In particular, the Ginicoefficient is most sensitive to changes in $\hat{q}_{i}$ around the mean; the mean log deviation is most sensitive to changes in $\hat{q}_{i}$ at the bottom of the distribution; and the coefficient of variation is most sensitive to changes at the top end of the distribution. The Theil index is the only index that has constant sensitivity to changes in $\hat{q}_{i}$ across all ranges of the distribution. The precise definitions of the four inequality indices are given in Appendix I.

\footnotetext{
${ }^{16}$ While it is common to also control for firm size, this is not appropriate in our case because according to our model, the firm size distribution depends directly on the extent to which financial sectors are liberalized.
}

${ }^{17}$ We use the logarithm rather than the level of $\mathrm{Q}$ because, given a concave production function, the distribution of $\log (\mathrm{Q})$ better reflects the underlying distribution of capital than the distribution of Q itself. Indeed, in our data set the distribution of Q itself is skewed to the right, while the distribution of the logarithm of Q is close to normal.

${ }^{18}$ In the absence of data on the year of establishment for Thailand, we measure the age of Thai firms as the difference between the current year and the year in which the firm was first listed at the Thai stock exchange. 


\section{DAta Description}

\section{A. Financial Liberalization Data}

One major drawback of previous studies on financial liberalization has been the lack of a comprehensive cross-country dataset that captures all the facets and gradations of financial reform. Previous measures of liberalization typically referred to a one-time change in rules (e.g., Bekaert and Harvey, 2000), which limited investigations to episodes of liberalization. An important contribution of this paper is that it uses a newly constructed financial liberalization index, covering 36 countries over the 24-year period from 1973 to 1996.

Our financial liberalization index takes as inputs the following six policy dimensions:

- Credit controls, including directed credit toward favored sectors or industries, ceilings on credit toward other sectors, and excessively high reserve requirements.

- Interest rate controls, including cases where the government directly controls interest rates, or where floors, ceilings, or interest rate bands exist.

- $\quad$ Entry barriers, including licensing requirements, limits to the participation of foreign banks, and restrictions relating to bank specialization or the establishment of universal banks.

- $\quad$ Regulations, including operational restrictions (e.g., on staffing, branching and advertising) which are considered repression, as well as prudential regulations, which are considered reforms.

\section{- State ownership in the financial sector.}

- $\quad$ Restrictions on international financial transactions, including restrictions on capital and current account convertibility, and the use of multiple exchange rates.

Along each dimension, a country is given a score on a graded scale, with zero corresponding to being fully repressed, one to partially repressed, two to largely liberalized, and three to fully liberalized. ${ }^{19}$ Policy changes, then, denote shifts in a country's score on this scale in a given year. In some cases, such as when all state-owned banks are privatized all at once, or when controls on all interest rates are simultaneously abolished, policy changes will correspond to jumps of more than one unit along that dimension. Reversals, such as the imposition of capital controls or

\footnotetext{
${ }^{19}$ Although the gradations are necessarily subjective, some guidelines were used to reduce the subjectivity. For example, interest rates were considered fully repressed where the government set all interest rates, partially repressed where interest rates were allowed to vary within a band or subject to a ceiling or floor, largely liberalized if some interest rates were allowed to be completely market-determined (or if new floating rate instruments were introduced), and fully liberalized where all interest rate restrictions were removed.
} 
interest rate controls, are recorded as shifts from a higher to a lower score. Given its detailed construction, the database allows a much more precise determination of the magnitude and timing of various events in the financial liberalization process. A detailed description of financial policy changes for the five countries included in this study can be found in Appendix Table 1. Further details on the financial liberalization index can be found in Abiad and Mody (2003).

\section{B. Corporate Finance Data}

To compute Tobin's Q, we use firm-level data from the International Finance Corporation's (IFC) Corporate Finance Database. Unlike other sources of firm-level data, such as Worldscope or Global Vantage, this IFC database is unique in that it covers emerging markets for most of the 1980 s, which is the period during which much of the financial liberalization in emerging markets took place.

The original IFC Corporate Finance Database contains annual information on a maximum of the 100 largest publicly traded, non-financial firms in thirteen developing countries: Argentina, Brazil, India, Indonesia, Jordan, Korea, Malaysia, Mexico, Pakistan, Peru, Thailand, Turkey, and Zimbabwe. The data are derived from listed company financial information, generally published in the yearbooks of stock markets. Since the early years of the sample did not contain data of sufficiently high quality for several countries (e.g., Malaysia and Thailand), the sample for these countries begins after 1980. For some of the smaller countries, fewer than 100 firms were traded or met the data availability criteria, which resulted in smaller samples. ${ }^{20}$

From the original set of thirteen countries mentioned above, we were able to use five. First, we eliminated countries that experienced hyperinflationary episodes, which introduces large errors in balance sheet data. Second, we eliminated countries with insufficient time coverage, particularly around the period of financial liberalization. Third, we dropped countries that lacked the data required to compute Tobin's Q or our control variables. Finally, we dropped countryyear observations if they contained too few firms for a dispersion measure to be calculated with sufficient confidence. This left us with five countries: India, Jordan, Korea, Malaysia and Thailand; the same five countries used by Chari and Henry (2003) for evaluating the impact of capital market liberalization. The data coverage for each country is summarized in Table $1 .^{21}$

${ }^{20}$ The IFC's collection criteria were (1) the availability of sufficiently high-quality data for a reasonably large sample of firms; and (2) representation of at least one country from each continent. More details on the data sources used for each country are given in Singh and Hamid (1992) and Booth and others (2001).

${ }^{21}$ We used slightly fewer observations than mentioned in Table 2, because of the need to remove some outliers. We eliminated outliers by first taking the logarithm of Q, the distribution of which is close to normal, and then removing all observations further than three standard deviations from the mean. We confirmed that our results were robust to using different procedures for removing outliers, e.g., excluding all observations with $Q>50$ before calculating the standard deviations. 
The fact that the IFC database only includes large, publicly listed firms creates a bias against detecting a positive effect of liberalization on allocative efficiency, and therefore would strengthen, rather than weaken, any finding of such a positive effect. Large firms are more likely to be well-connected, and less likely to be financially constrained even under financial repression. Hence, if we observe a decrease in dispersion even among these large firms, then the efficiency gains are likely to be even larger if one could measure dispersion across firms of all sizes. Another advantage of focusing on publicly listed firms is that information on the activities of these firms is easy for investors to obtain, and therefore informational problems should be minimal.

The fact that we use an unbalanced sample is another factor that biases us against finding a decrease in dispersion. If we used a balanced sample, the data would contain only firms that survived throughout the sample period, hence the sample would likely be biased towards firms that did not face financing constraints. An unbalanced sample would have the same bias only if the distribution across new entrants (i.e., newly listed companies on the stock market) is the same as the distribution across old entrants, that is, as long as the entry barriers to the securities market remain unchanged. However, financial liberalization should be expected to lower the entry barriers for firms that used to have financing constraints, in which case the variation among new entrants will be larger, thus increasing the dispersion in Tobin's Q in the unbalanced sample.

Table 1. International Finance Corporation (IFC) Corporate Financial Database Coverage (Number of firms per year)

\begin{tabular}{lcccccccc}
\hline Country & 1980 & 1981 & 1982 & 1983 & 1984 & 1985 & 1986 & 1987 \\
\hline India & 40 & 64 & 76 & 79 & 85 & 85 & 83 & 78 \\
Jordan & 27 & 24 & 30 & 32 & 33 & 33 & 35 & 33 \\
Korea & 90 & 89 & 90 & 87 & 90 & 89 & 88 & 89 \\
Malaysia & & & & 85 & 90 & 93 & 94 & 96 \\
Thailand & & & & & 33 & 36 & 38 & 47 \\
\hline Total & 157 & 177 & 196 & 283 & 331 & 336 & 338 & 343 \\
& & & & & & & & \\
\hline Country & 1988 & 1989 & 1990 & 1991 & 1992 & 1993 & 1994 & \\
\hline India & 63 & 79 & 84 & 79 & 75 & & & \\
Jordan & 33 & 33 & 31 & 33 & 32 & 31 & 31 & \\
Korea & 88 & 87 & 87 & 84 & 84 & 73 & 74 & \\
Malaysia & 86 & 87 & 94 & 87 & 89 & 91 & 88 & \\
Thailand & 59 & 62 & 62 & 61 & 60 & 57 & 58 & \\
\hline Total & 329 & 348 & 358 & 344 & 340 & 252 & 251 & \\
\hline
\end{tabular}

\section{DesCriptive Statistics}

In this section, we report simple descriptive statistics of financial liberalization and the dispersion in Tobin's Q, and provide evidence for a negative unconditional correlation between the two, as predicted by our model. In the next section, we present results of more formal panel 
regressions and robustness checks that control for omitted variables, time trends, and endogeneity, and show that this negative relationship is highly robust.

We start by comparing the average dispersion in Tobin's Q before and after financial liberalization, using the liberalization dates specified by Demirgüc-Kunt and Detragiache (1998), which were based solely on interest rate liberalization. The liberalization dates are 1991 for India, 1988 for Jordan, 1991 for Korea, 1987 for Malaysia, ${ }^{22}$ and 1989 for Thailand. This preand post-liberalization exercise does not make full use of the graded nature of the financial liberalization index, which we take advantage of in the panel regressions, but it is an illustrative starting point for our analysis.

Given the constraints regarding data availability and reliability, the results are supportive of a quality effect: in all cases, the dispersion in Q declined (i.e., allocative efficiency improved) following financial liberalization, although the degree of decline varied across countries. As Figure 1 shows, the largest increases in efficiency took place in Jordan and India. The Gini coefficient for Jordan, for example, dropped by 41 percent, from 0.30 to 0.17 , while in India it decreased by 19 percent, from 0.25 to 0.20 . Interestingly, the East Asian countries in our sample showed smaller gains from financial liberalization, with the Gini coefficient decreasing by 11 percent in Malaysia, 7 percent in Thailand and by only 2 percent in Korea.

Comparing the relative decreases measured by the Gini coefficient and the Theil index in Figures 1 and 2, we see that the percentage decline measured by the Theil index is somewhat larger than that measured using the Gini coefficient. Because the Gini coefficient is more sensitive to changes to changes around the center of the distribution, one interpretation of this is that most of the decrease in dispersion is coming from the tail regions. That is, the firms most affected by liberalization are those that had benefited most from financial repression (low Q) and those that were most constrained by it (high Q). The mean log deviation measure, which is more sensitive to changes in the lower tail, and the measure based on the coefficient of variation, which is more sensitive to the upper tail, also show a greater decline than the Gini coefficient, confirming that both low Q and high Q firms were affected by financial liberalization.

The general fall in dispersion after liberalization is also apparent from Figure 2, which shows the evolution of financial liberalization and the dispersion in Q over time. Each chart contains timeplots of the Gini coefficient and Theil index; the other two entropy-based indices are very similar to that of the Theil index. The index of financial liberalization is also plotted, with a value of zero corresponding to full financial repression and a value of one corresponding to full financial liberalization.

Another pattern that can be observed in Figure 2 is that several countries experienced a gradual increase in dispersion - a worsening of allocative efficiency - up until a few years before liberalization begins. Taking Jordan as an example, one observes a gradual rise in dispersion

${ }^{22}$ Interest rate decontrol in Malaysia occurred in October 1978, which predates both DemirgücKunt and Detragiache's sample and ours. However Malaysia reimposed controls in 1985 and liberalized them in 1987. 


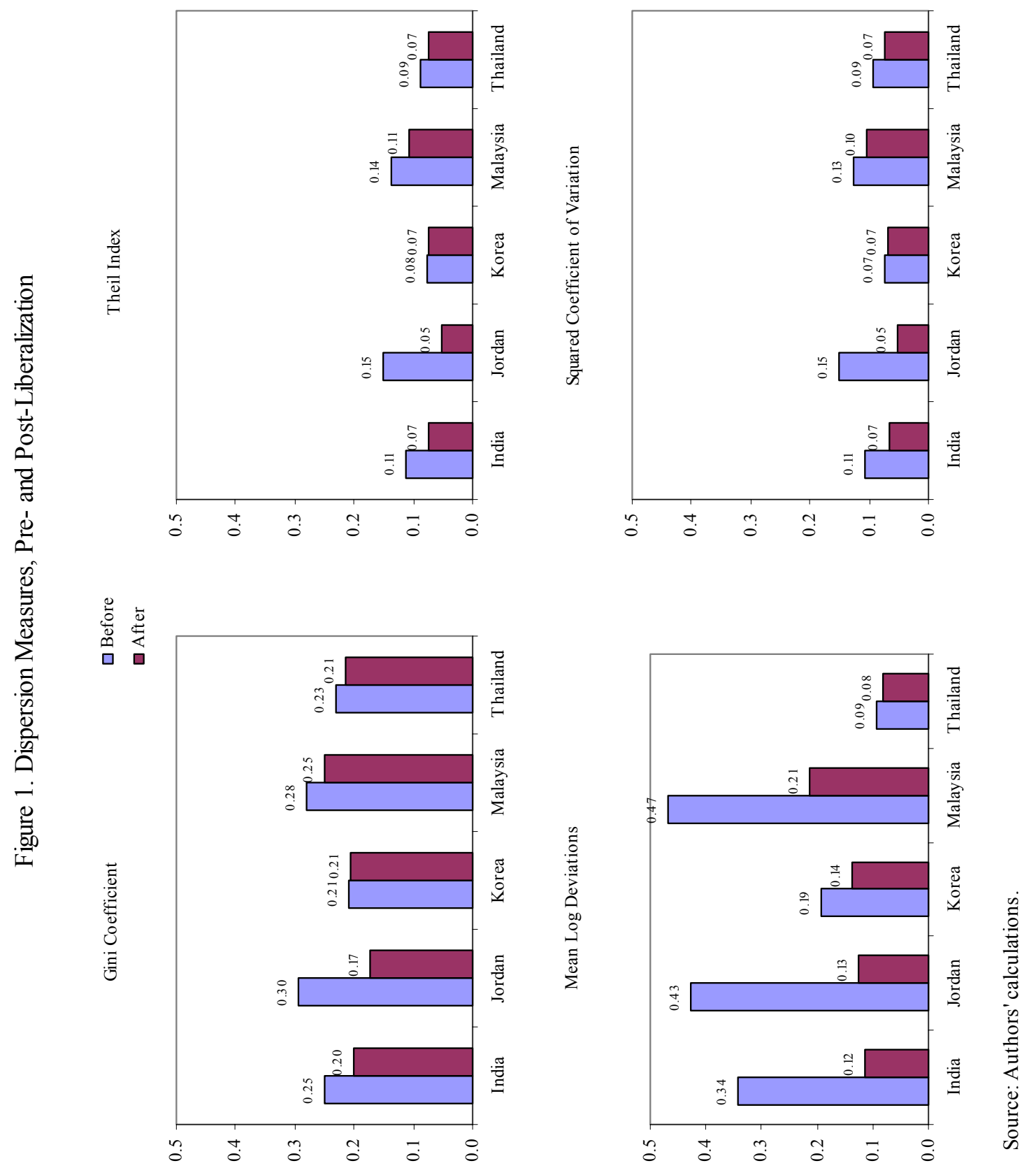




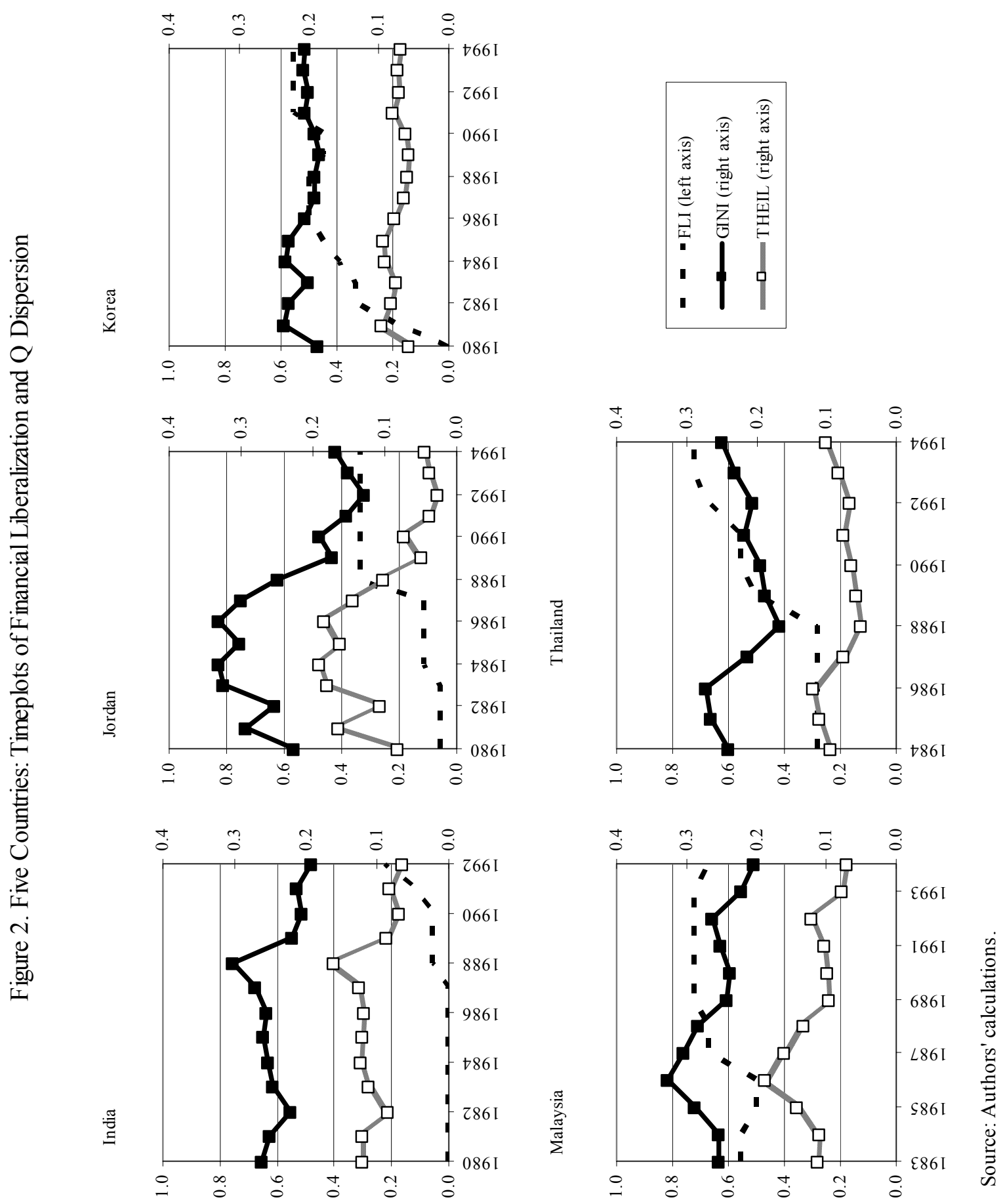


from 1980 to 1987, at which point dispersion begins to fall. A similar hump-shaped pattern can be seen in India, and to a lesser extent in Malaysia. This suggests that credit allocation worsened first, before financial liberalization was eventually implemented. ${ }^{23}$ One mechanism by which this can happen is if credit is constantly channeled to the same firms, and is denied to other firms, over a number of years. This would bring about a steady decrease in the marginal product of capital for well-connected firms, as money gets poured into successively less productive investments. For those firms that are severely credit-constrained, marginal productivity may remain high or even rise, if they are unable to maintain even existing projects.

\section{Panel Regressions}

In this section, we use a more formal approach to test the significance and robustness of the effect of financial liberalization on the variation in returns across firms. First, we run panel regressions of dispersion in $\mathrm{Q}$ on the financial liberalization index, while controlling for previously omitted variables that can also affect dispersion, including (1) cumulative inflation, (2) trade openness, (3) private credit growth, (4) stock market capitalization, and (5) stock market turnover. The results of these regressions are reported in sections A and B. We then control for potential simultaneity and endogeneity, by using the Arellano-Bond dynamic panel estimator, and show in section $\mathrm{C}$ that our results generally hold up against this stringent test as well. Finally, we run several other robustness checks (e.g., including time dummies, crisis dummies, and interaction variables), which are summarized in section $\mathrm{D}$, all of which strengthen our confidence that financial liberalization genuinely improves allocative efficiency.

\section{A. Controlling for Inflation and Trade Openness}

Even though we adjusted the book value of tangible assets for inflation to better approximate their replacement cost, it is possible that there are additional effects of inflation on the dispersion of Q. First, changes in the prices of tangible assets such as land are not homogenous across firms, and the variance in inflation rates across different assets is likely to increase with the common inflation rate. Second, higher inflation may affect the difference between the market value of debt and the book value of debt.

To understand the effect of inflation on the dispersion in observed Q, let $\xi_{i t}=\tilde{q}_{i t}-q_{i t}$ denote the measurement error, i.e. the difference between observed $\mathrm{Q}$ and true Q. Assuming that the measurement error is drawn from a similar distribution each time, we can write, in parametric form,

$$
\xi_{i t} \sim F\left(\lambda_{t}, \theta_{t}^{2}\right)
$$

where $\lambda_{t}$ is the time-variant mean of the measurement error (e.g., inflation common to all firms), and $\theta_{t}$ is its time-variant variance (e.g., the heterogeneous component of inflation). Our measures of dispersion are affected by this measurement error in two ways. First, the common

${ }^{23}$ One interesting possibility is that the gradual worsening in allocative efficiency itself spurs reform and makes liberalization more likely. 
measurement error $\lambda_{t}$ creates a downward bias in our estimates of dispersion, just as giving each citizen of a country the same lump-sum payment reduces the income inequality in that country. Second, the heterogeneous component $\theta_{t}$ creates an upward bias in our estimates of dispersion. Since we already adjusted tangible assets by common inflation, the effect of inflation on dispersion is likely to operate largely through the heterogeneous component.

While we do not have data on location-specific or industry-specific inflation rates, both the mean $\lambda_{t}$ and the heterogeneous component $\theta_{t}$ of the measurement error could be associated with aggregate inflation in a country, because the aggregate inflation rate is simply a weighted average of location-specific and industry-specific inflation rates. A simple way to control for heterogeneous inflation is therefore to regress dispersion on the overall inflation rate. Since measurement error due to asset-specific inflation cumulates over time, we use cumulative fiveyear inflation as one of the controls in our regression. ${ }^{24}$

In addition to controlling for cumulative inflation, we use trade openness as a control, for two reasons. First, trade openness may act as a proxy for other reforms that may improve allocative efficiency independently of financial liberalization. For example, exports and imports are directly affected by product market reforms that involve price or quantity restrictions on goods and services. Second, countries that are more open to trade flows are generally also more open to financial flows, and a more globally integrated financial sector may improve efficiency both through better allocation and better valuation. ${ }^{25}$

Even after controlling for inflation and trade openness, we find that the effect of financial liberalization on dispersion in Q is still negative and is highly significant. As Table 2 shows, this result is robust to using different measures of dispersion, as well as to using a fixed effects or random effects model. Using a fixed effects model, the effect of cumulative inflation is negative but generally insignificant, while the effect of trade openness is negative and significant at the 5 percent level. Using random effects, the effect of cumulative inflation is negative and significant, while the effect of trade openness is insignificant and with generally mixed signs. A Hausman test ${ }^{26}$ rejects the random effects model in favor of the fixed effects model, so we use fixed effects for our subsequent regressions reported below.

${ }^{24}$ Using three-year cumulated inflation or seven-year cumulated inflation as alternatives did not change any of the results.

${ }^{25}$ Although one dimension of the financial liberalization index measures restrictions on international financial flows, liberalization along this dimension does not imply global integration; some countries have relatively small international flows despite having few restrictions on these transactions. Using actual financial flows is also unsatisfactory; greater financial integration is associated with increased flows on average, but not in any given year.

${ }^{26}$ Random effects requires that the error term is uncorrelated with the regressors. Under this null hypothesis, the random effects estimator is consistent and efficient, but under the alternative it is inconsistent. The fixed effects estimator is consistent under both the null and the alternative. The Hausman test is a based on a comparison of the fixed effects and random effects estimates. 
Table 2. Fixed Effects and Random Effects

\begin{tabular}{|c|c|c|c|c|c|c|c|c|}
\hline & \multicolumn{4}{|c|}{ Fixed Effects } & \multicolumn{4}{|c|}{ Random Effects } \\
\hline & Gini & Theil & M.L.D. & C.V.Sq. & Gini & Theil & M.L.D. & C.V.Sq. \\
\hline \multirow[t]{2}{*}{ Financial liberalization } & -0.215 & -0.459 & -0.776 & -0.448 & -0.2 & -0.441 & -0.744 & -0.404 \\
\hline & {$[4.82]^{* * *}$} & {$[4.91]^{* * *}$} & {$[3.34]^{* * *}$} & {$[5.02]^{* * *}$} & {$[4.62]^{* * *}$} & {$[4.87]^{* * *}$} & {$[3.50]^{* * *}$} & {$[4.74] * * *$} \\
\hline \multirow[t]{2}{*}{ Cumulative inflation } & -0.941 & -2.081 & -0.753 & -2.579 & -1.918 & -3.751 & -2.226 & -4.619 \\
\hline & {$[1.31]$} & [1.39] & {$[0.20]$} & {$[1.80]^{*}$} & {$[2.59]^{* * *}$} & {$[2.48]^{* *}$} & {$[0.64]$} & {$[3.11]^{* * *}$} \\
\hline \multirow[t]{2}{*}{ Trade openness } & -0.333 & -0.615 & -0.422 & -0.696 & 0.056 & 0.086 & 0.229 & 0.114 \\
\hline & {$[2.35]^{* *}$} & {$[2.08]^{* *}$} & {$[0.57]$} & {$[2.46]^{* *}$} & {$[0.81]$} & {$[0.54]$} & {$[0.56]$} & {$[0.87]$} \\
\hline Observations & 57 & 57 & 57 & 57 & 57 & 57 & 57 & 57 \\
\hline Number of countries & 5 & 5 & 5 & 5 & 5 & 5 & 5 & 5 \\
\hline \multirow[t]{3}{*}{ R-squared } & 0.49 & 0.49 & 0.25 & 0.52 & 0.19 & 0.18 & 0.09 & 0.24 \\
\hline & & & \multirow{2}{*}{\multicolumn{2}{|c|}{ Hausman Test Statistic: }} & 62.32 & 43.89 & 2.65 & 47.22 \\
\hline & & & & & 0.00 & 0.00 & 0.45 & 0.00 \\
\hline
\end{tabular}

Notes: Absolute values of $\mathrm{t}$ statistics are in brackets.

* significant at 10 percent; ** significant at 5 percent; *** significant at 1 percent.

In the Hausman Test of FE vs. RE, the null hypothesis is that the Random Effects model is valid.

\section{B. Controlling for Financial Deepening}

As we discussed in our literature review, several recent studies document a positive impact from financial deepening on allocative efficiency. A relevant question to ask is, therefore: what matters more for allocative efficiency, financial liberalization or financial deepening? The answer has important policy implications, since a country can achieve financial deepening without financial liberalization, and vice versa.

In order to separate the effects of financial liberalization and financial deepening, we add to our baseline fixed effects regression three different measures of financial deepening. The first is bank credit to the private sector relative to GDP, an indicator of the depth of the banking sector. The second and the third are indicators of stock market development: stock market capitalization relative to GDP, and stock market turnover relative to market capitalization, which captures how liquid the stock market is. Data for these three indicators were taken from the World Bank's (2001) Financial Development and Structure database.

The results strongly suggest that financial liberalization operates separately from financial deepening, and that the former is more important than the latter for improving allocative efficiency. Table 3 presents these regression results, with one panel for each inequality measure. When the financial liberalization index and the three financial deepening indicators are included in separate regressions (columns 1 through 4), all coefficients are correctly signed (negative), but only financial liberalization and stock market turnover are significant. Financial liberalization is significant at the 1-percent level, while stock market turnover is significant at the 5-percent level. However, the more commonly used measures of financial deepening — bank credit and stock market capitalization — are both insignificant. 
Table 3. Fixed-Effects Regressions with Financial Development Indicators

\begin{tabular}{|c|c|c|c|c|c|c|c|}
\hline \multirow[b]{2}{*}{ Financial liberalization } & \multicolumn{7}{|c|}{ Dependent Variable: Gini Coefficient } \\
\hline & $\begin{array}{l}-0.215 \\
{[4.82]^{* * *}}\end{array}$ & & & & $\begin{array}{l}-0.267 \\
{[5.52]^{* * *}}\end{array}$ & $\begin{array}{l}-0.217 \\
{[4.61]^{* * *}}\end{array}$ & $\begin{array}{l}-0.210 \\
{[5.05]^{* * *}}\end{array}$ \\
\hline Private credit & & $\begin{array}{l}-0.029 \\
{[0.24]}\end{array}$ & & & $\begin{array}{l}0.280 \\
{[2.29]^{* *}}\end{array}$ & & \\
\hline Stock market capitalization & & & $\begin{array}{l}-0.042 \\
{[1.13]}\end{array}$ & & & $\begin{array}{l}0.005 \\
{[0.14]}\end{array}$ & \\
\hline Stock market turnover & & & & $\begin{array}{l}-0.093 \\
{[2.59]^{* *}}\end{array}$ & & & $\begin{array}{l}-0.101 \\
{[2.96]^{* * *}}\end{array}$ \\
\hline Cumulative inflation & $\begin{array}{l}-0.941 \\
{[1.31]}\end{array}$ & $\begin{array}{l}-0.061 \\
{[0.08]}\end{array}$ & $\begin{array}{l}-0.452 \\
{[0.56]}\end{array}$ & $\begin{array}{l}-0.426 \\
{[0.61]}\end{array}$ & $\begin{array}{l}-0.480 \\
{[0.67]}\end{array}$ & $\begin{array}{l}-0.893 \\
{[1.11]}\end{array}$ & $\begin{array}{l}-1.365 \\
{[2.00]^{*}}\end{array}$ \\
\hline Trade openness & $\begin{array}{l}-0.333 \\
{[2.35]^{* *}}\end{array}$ & $\begin{array}{l}-0.604 \\
{[4.31]^{* * *}}\end{array}$ & $\begin{array}{l}-0.497 \\
{[2.94]^{* * *}}\end{array}$ & $\begin{array}{l}-0.468 \\
{[3.29]^{* * *}}\end{array}$ & $\begin{array}{l}-0.347 \\
{[2.56]^{* *}}\end{array}$ & $\begin{array}{l}-0.344 \\
{[2.11]^{* *}}\end{array}$ & $\begin{array}{l}-0.149 \\
{[1.02]}\end{array}$ \\
\hline $\begin{array}{l}\text { Observations } \\
\text { Number of countries } \\
\text { R-squared }\end{array}$ & $\begin{array}{l}57 \\
5 \\
0.49\end{array}$ & $\begin{array}{l}66 \\
5 \\
0.26\end{array}$ & $\begin{array}{l}66 \\
5 \\
0.28\end{array}$ & $\begin{array}{l}66 \\
5 \\
0.34\end{array}$ & $\begin{array}{l}57 \\
5 \\
0.54\end{array}$ & $\begin{array}{l}57 \\
5 \\
0.49\end{array}$ & $\begin{array}{l}57 \\
5 \\
0.57\end{array}$ \\
\hline & \multicolumn{7}{|c|}{ Dependent Variable: Theil Index } \\
\hline Financial liberalization & $\begin{array}{l}-0.459 \\
{[4.91]^{* * *}}\end{array}$ & & & & $\begin{array}{l}-0.557 \\
{[5.47]^{* * *}}\end{array}$ & $\begin{array}{l}-0.456 \\
{[4.63]^{* * *}}\end{array}$ & $\begin{array}{l}-0.446 \\
{[5.20]^{* * *}}\end{array}$ \\
\hline Private credit & & $\begin{array}{l}-0.089 \\
{[0.36]}\end{array}$ & & & $\begin{array}{l}0.536 \\
{[2.08]^{* *}}\end{array}$ & & \\
\hline Stock market capitalization & & & $\begin{array}{l}-0.107 \\
{[1.37]}\end{array}$ & & & $\begin{array}{l}-0.007 \\
{[0.09]}\end{array}$ & \\
\hline Stock market turnover & & & & $\begin{array}{l}-0.195 \\
{[2.59]^{* *}}\end{array}$ & & & $\begin{array}{l}-0.224 \\
{[3.15]^{* * *}}\end{array}$ \\
\hline Cumulative inflation & $\begin{array}{l}-2.081 \\
{[1.39]}\end{array}$ & $\begin{array}{l}-0.278 \\
{[0.17]}\end{array}$ & $\begin{array}{l}-1.226 \\
{[0.72]}\end{array}$ & $\begin{array}{l}-0.977 \\
{[0.67]}\end{array}$ & $\begin{array}{l}-1.198 \\
{[0.79]}\end{array}$ & $\begin{array}{l}-2.145 \\
{[1.28]}\end{array}$ & $\begin{array}{l}-3.017 \\
{[2.14]^{* *}}\end{array}$ \\
\hline Trade openness & $\begin{array}{l}-0.615 \\
{[2.08]^{* *}}\end{array}$ & $\begin{array}{l}-1.201 \\
{[4.07]^{* * *}}\end{array}$ & $\begin{array}{l}-0.933 \\
{[2.64]^{* *}}\end{array}$ & $\begin{array}{l}-0.918 \\
{[3.07]^{* * *}}\end{array}$ & $\begin{array}{l}-0.642 \\
{[2.24]^{* *}}\end{array}$ & $\begin{array}{l}-0.600 \\
{[1.77]^{*}}\end{array}$ & $\begin{array}{l}-0.208 \\
{[0.69]}\end{array}$ \\
\hline Observations & 57 & 66 & 66 & 66 & 57 & 57 & 57 \\
\hline Number of countries & 5 & 5 & 5 & 5 & 5 & 5 & 5 \\
\hline R-squared & 0.49 & 0.25 & 0.27 & 0.32 & 0.53 & 0.49 & 0.57 \\
\hline
\end{tabular}

Notes: Absolute value of $\mathrm{t}$ statistics are in brackets.

* significant at 10 percent; ** significant at 5 percent; *** significant at 1 percent. 
Table 3 (concluded). Fixed-Effects Regressions with Financial Development Indicators

\begin{tabular}{|c|c|c|c|c|c|c|c|}
\hline \multirow[b]{2}{*}{ Financial liberalization } & \multicolumn{7}{|c|}{ Dependent Variable: Mean Log Deviation } \\
\hline & $\begin{array}{l}-0.776 \\
{[3.34]^{* * *}}\end{array}$ & & & & $\begin{array}{l}-0.940 \\
{[3.62]^{* * *}}\end{array}$ & $\begin{array}{l}-0.676 \\
{[2.81]^{* * *}}\end{array}$ & $\begin{array}{l}-0.751 \\
{[3.40]^{* * *}}\end{array}$ \\
\hline Private credit & & $\begin{array}{l}0.113 \\
{[0.20]}\end{array}$ & & & $\begin{array}{l}0.895 \\
{[1.36]}\end{array}$ & & \\
\hline Stock market capitalization & & & $\begin{array}{l}-0.380 \\
{[2.17]^{* *}}\end{array}$ & & & $\begin{array}{l}-0.277 \\
{[1.44]}\end{array}$ & \\
\hline Stock market turnover & & & & $\begin{array}{l}-0.307 \\
{[1.72]^{*}}\end{array}$ & & & $\begin{array}{l}-0.465 \\
{[2.56]^{* *}}\end{array}$ \\
\hline Cumulative inflation & $\begin{array}{l}-0.753 \\
{[0.20]}\end{array}$ & $\begin{array}{l}3.307 \\
{[0.89]}\end{array}$ & $\begin{array}{l}-1.126 \\
{[0.29]}\end{array}$ & $\begin{array}{l}1.585 \\
{[0.46]}\end{array}$ & $\begin{array}{l}0.721 \\
{[0.19]}\end{array}$ & $\begin{array}{l}-3.315 \\
{[0.81]}\end{array}$ & $\begin{array}{l}-2.701 \\
{[0.75]}\end{array}$ \\
\hline Trade openness & $\begin{array}{l}-0.422 \\
{[0.57]}\end{array}$ & $\begin{array}{l}-1.738 \\
{[2.57]^{* *}}\end{array}$ & $\begin{array}{l}-0.703 \\
{[0.89]}\end{array}$ & $\begin{array}{l}-1.245 \\
{[1.76]^{*}}\end{array}$ & $\begin{array}{l}-0.467 \\
{[0.64]}\end{array}$ & $\begin{array}{l}0.147 \\
{[0.18]}\end{array}$ & $\begin{array}{l}0.425 \\
{[0.55]}\end{array}$ \\
\hline Observations & 57 & 66 & 66 & 66 & 57 & 57 & 57 \\
\hline Number of countries & 5 & 5 & 5 & 5 & 5 & 5 & 5 \\
\hline R-squared & 0.25 & 0.10 & 0.17 & 0.15 & 0.27 & 0.28 & 0.34 \\
\hline
\end{tabular}

Dependent Variable: Squared Coefficient of Variation

\begin{tabular}{|c|c|c|c|c|c|c|c|}
\hline Financial liberalization & $\begin{array}{l}-0.448 \\
{[5.02]^{* * *}}\end{array}$ & & & & $\begin{array}{l}-0.547 \\
{[5.65]^{* * *}}\end{array}$ & $\begin{array}{l}-0.449 \\
{[4.77]^{* * *}}\end{array}$ & $\begin{array}{l}-0.437 \\
{[5.28]^{* * *}}\end{array}$ \\
\hline Private credit & & $\begin{array}{l}-0.110 \\
{[0.45]}\end{array}$ & & & $\begin{array}{l}0.542 \\
{[2.21]^{* *}}\end{array}$ & & \\
\hline Stock market capitalization & & & $\begin{array}{l}-0.106 \\
{[1.39]}\end{array}$ & & & $\begin{array}{l}0.003 \\
{[0.03]}\end{array}$ & \\
\hline Stock market turnover & & & & $\begin{array}{l}-0.190 \\
{[2.60]^{* *}}\end{array}$ & & & $\begin{array}{l}-0.206 \\
{[3.01]^{* * *}}\end{array}$ \\
\hline Cumulative inflation & $\begin{array}{l}-2.579 \\
{[1.80]^{*}}\end{array}$ & $\begin{array}{l}-0.910 \\
{[0.58]}\end{array}$ & $\begin{array}{l}-1.794 \\
{[1.08]}\end{array}$ & $\begin{array}{l}-1.534 \\
{[1.08]}\end{array}$ & $\begin{array}{l}-1.686 \\
{[1.17]}\end{array}$ & $\begin{array}{l}-2.555 \\
{[1.59]}\end{array}$ & $\begin{array}{l}-3.439 \\
{[2.53]^{* *}}\end{array}$ \\
\hline Trade openness & $\begin{array}{l}-0.696 \\
{[2.46]^{* *}}\end{array}$ & $\begin{array}{l}-1.240 \\
{[4.34]^{* * *}}\end{array}$ & $\begin{array}{l}-0.980 \\
{[2.85]^{* * *}}\end{array}$ & $\begin{array}{l}-0.970 \\
{[3.35]^{* * *}}\end{array}$ & $\begin{array}{l}-0.724 \\
{[2.66]^{* *}}\end{array}$ & $\begin{array}{l}-0.701 \\
{[2.16]^{* *}}\end{array}$ & $\begin{array}{l}-0.322 \\
{[1.11]}\end{array}$ \\
\hline Observations & 57 & 66 & 66 & 66 & 57 & 57 & 57 \\
\hline Number of countries & 5 & 5 & 5 & 5 & 5 & 5 & 5 \\
\hline R-squared & 0.52 & 0.28 & 0.30 & 0.36 & 0.57 & 0.52 & 0.60 \\
\hline
\end{tabular}

Notes: Absolute value of $\mathrm{t}$ statistics are in brackets.

* significant at 10 percent; ** significant at 5 percent; *** significant at 1 percent.

When liberalization is combined with any of the three financial deepening indicators (columns 5 through 7), it remains significant, but the coefficients on bank credit and stock market capitalization occasionally become wrongly signed (positive). In the case of bank credit, the 
coefficient is often significantly positive, which would suggest a worsening of allocation as the banking sector develops, after one has controlled for the effect of liberalization. ${ }^{27}$

The effect of stock market turnover on dispersion is robust to the inclusion of liberalization, which can be explained in two ways. One explanation is that a liquid stock market has an independent effect on allocative efficiency, possibly because stock market liquidity makes it easier for firms to issue new equity. The other explanation is that high stock market turnover may result in more accurate stock market valuations, which can directly decrease the dispersion in $Q$, because the market valuation of equity is contained in the numerator of Q. Hence, by controlling for stock market development, we are more confident that the effect of liberalization we find is not due simply to the fact that liberalization may lead to better valuations, but due to improved allocative efficiency.

\section{Controlling for Persistence and Endogeneity}

Since our financial liberalization index as well as our dispersion measures display strong persistence over time (see Figure 2), it is important to ensure that the negative correlation found between the two series does not merely reflect spurious correlation. In addition, we also need to control for endogeneity and simultaneity, to ensure that the relationship we observe between liberalization and efficiency is actually causal rather than simply incidental.

To control for both strong persistence and for joint endogeneity and simultaneity, we reestimate our regressions using the Arellano and Bond (1991) GMM dynamic panel estimator. We first allow for the possibility of persistence by including lagged values of the dependent variable in the regression. We then difference the regression equation to focus on the effect of changes in the regressors on changes in dispersion of Q (eliminating the possibility of spurious regression in the case of integrated variables) and to eliminate any omitted variable bias created by unobserved country fixed effects. Finally, we instrument the right-hand side variables (the differenced values of the original regressors) using lagged levels of the original regressors to eliminate potential parameter inconsistency arising from simultaneity bias. ${ }^{28}$

Despite the very limited sample size, our main results survive this quite stringent test. Table 4 shows that the coefficient on financial liberalization remains correctly signed in all the regressions, and is statistically significant in the majority of cases. Stock market turnover is also correctly signed in all the regressions, and although it is not significant when included by itself (column 4), it is significant when liberalization is added as a control (column 7).

${ }^{27}$ The ambiguous effect of private credit growth suggests that there are two opposite effects, as also noted by Loayza and Ranciere (2001): a long-run positive effect whereby private credit growth (reflecting the extent of financial intermediation) positively affects allocative efficiency; but also a potential short-run negative effect when credit booms lead to a misallocation of credit.

${ }^{28}$ Specification tests based on the absence of second-order serial correlation are used. The null hypothesis of no second-order serial correlation is not rejected, indicating that the lagged levels are valid instruments. 
Table 4. Arellano-Bond Dynamic Panel Regressions

\begin{tabular}{|c|c|c|c|c|c|c|c|}
\hline \multirow[b]{2}{*}{ Financial liberalization } & \multicolumn{7}{|c|}{ Dependent Variable: Gini Coefficient } \\
\hline & $\begin{array}{l}-0.112 \\
{[1.64]}\end{array}$ & & & & $\begin{array}{l}-0.130 \\
{[1.84]^{*}}\end{array}$ & $\begin{array}{l}-0.066 \\
{[1.09]}\end{array}$ & $\begin{array}{l}-0.176 \\
{[3.42]^{* * *}}\end{array}$ \\
\hline Private credit & & $\begin{array}{l}0.175 \\
{[1.19]}\end{array}$ & & & $\begin{array}{l}0.334 \\
{[1.44]}\end{array}$ & & \\
\hline Stock market capitalization & & & $\begin{array}{l}0.110 \\
{[1.95]^{*}}\end{array}$ & & & $\begin{array}{l}0.098 \\
{[1.51]}\end{array}$ & \\
\hline Stock market turnover & & & & $\begin{array}{l}-0.053 \\
{[1.36]}\end{array}$ & & & $\begin{array}{l}-0.093 \\
{[2.11]^{* *}}\end{array}$ \\
\hline Cumulative inflation & $\begin{array}{l}0.363 \\
{[0.47]}\end{array}$ & $\begin{array}{l}0.509 \\
{[0.91]}\end{array}$ & $\begin{array}{l}1.088 \\
{[1.79]^{*}}\end{array}$ & $\begin{array}{l}0.473 \\
{[0.78]}\end{array}$ & $\begin{array}{l}0.022 \\
{[0.03]}\end{array}$ & $\begin{array}{l}0.780 \\
{[0.96]}\end{array}$ & $\begin{array}{l}0.285 \\
{[0.42]}\end{array}$ \\
\hline Trade openness & $\begin{array}{l}-0.204 \\
{[2.70]^{* * *}}\end{array}$ & $\begin{array}{l}-0.188 \\
{[2.65]^{* * *}}\end{array}$ & $\begin{array}{l}-0.369 \\
{[3.04]^{* * *}}\end{array}$ & $\begin{array}{l}-0.190 \\
{[1.60]}\end{array}$ & $\begin{array}{l}-0.144 \\
{[2.85]^{* * *}}\end{array}$ & $\begin{array}{l}-0.328 \\
{[2.93]^{* * *}}\end{array}$ & $\begin{array}{l}-0.089 \\
{[0.82]}\end{array}$ \\
\hline Lagged dependent variable & $\begin{array}{l}0.562 \\
{[4.81]^{* * *}}\end{array}$ & $\begin{array}{l}0.589 \\
{[15.28]^{* * *}}\end{array}$ & $\begin{array}{l}0.604 \\
{[9.71]^{* * *}}\end{array}$ & $\begin{array}{l}0.604 \\
{[9.39]^{* * *}}\end{array}$ & $\begin{array}{l}0.422 \\
{[3.94]^{* * *}}\end{array}$ & $\begin{array}{l}0.551 \\
{[5.67]^{* * *}}\end{array}$ & $\begin{array}{l}0.542 \\
{[5.04]^{* * *}}\end{array}$ \\
\hline $\begin{array}{l}\text { Observations } \\
\text { Number of countries } \\
\end{array}$ & $\begin{array}{l}49 \\
5 \\
\end{array}$ & $\begin{array}{l}56 \\
5 \\
\end{array}$ & $\begin{array}{l}56 \\
5 \\
\end{array}$ & $\begin{array}{l}56 \\
5 \\
\end{array}$ & $\begin{array}{l}49 \\
5 \\
\end{array}$ & $\begin{array}{l}49 \\
5 \\
\end{array}$ & $\begin{array}{l}49 \\
5 \\
\end{array}$ \\
\hline & \multicolumn{7}{|c|}{ Dependent Variable: Theil Index } \\
\hline Financial liberalization & $\begin{array}{l}-0.247 \\
{[1.89]^{*}}\end{array}$ & & & & $\begin{array}{l}-0.286 \\
{[1.99]^{* *}}\end{array}$ & $\begin{array}{l}-0.157 \\
{[1.31]}\end{array}$ & $\begin{array}{l}-0.387 \\
{[4.17]^{* * *}}\end{array}$ \\
\hline Private credit & & $\begin{array}{l}0.401 \\
{[1.45]}\end{array}$ & & & $\begin{array}{l}0.768 \\
{[1.56]}\end{array}$ & & \\
\hline Stock market capitalization & & & $\begin{array}{l}0.221 \\
{[1.85]^{*}}\end{array}$ & & & $\begin{array}{l}0.193 \\
{[1.41]}\end{array}$ & \\
\hline Stock market turnover & & & & $\begin{array}{l}-0.115 \\
{[1.33]}\end{array}$ & & & $\begin{array}{l}-0.205 \\
{[2.13]^{* *}}\end{array}$ \\
\hline Cumulative inflation & $\begin{array}{l}0.135 \\
{[0.07]}\end{array}$ & $\begin{array}{l}0.414 \\
{[0.26]}\end{array}$ & $\begin{array}{l}1.639 \\
{[1.05]}\end{array}$ & $\begin{array}{l}0.359 \\
{[0.21]}\end{array}$ & $\begin{array}{l}-0.662 \\
{[0.35]}\end{array}$ & $\begin{array}{l}0.957 \\
{[0.47]}\end{array}$ & $\begin{array}{l}-0.068 \\
{[0.04]}\end{array}$ \\
\hline Trade openness & $\begin{array}{l}-0.350 \\
{[2.10]^{* *}}\end{array}$ & $\begin{array}{l}-0.300 \\
{[2.02]^{* *}}\end{array}$ & $\begin{array}{l}-0.677 \\
{[3.16]^{* * *}}\end{array}$ & $\begin{array}{l}-0.309 \\
{[1.13]}\end{array}$ & $\begin{array}{l}-0.208 \\
{[1.90]^{*}}\end{array}$ & $\begin{array}{l}-0.594 \\
{[3.00]^{* * *}}\end{array}$ & $\begin{array}{l}-0.099 \\
{[0.42]}\end{array}$ \\
\hline Lagged dependent variable & $\begin{array}{l}0.483 \\
{[3.45]^{* * *}}\end{array}$ & $\begin{array}{l}0.505 \\
{[8.72]^{* * *}}\end{array}$ & $\begin{array}{l}0.529 \\
{[5.32]^{* * *}}\end{array}$ & $\begin{array}{l}0.524 \\
{[5.52]^{* * *}}\end{array}$ & $\begin{array}{l}0.330 \\
{[2.29]^{* *}}\end{array}$ & $\begin{array}{l}0.473 \\
{[3.48]^{* * *}}\end{array}$ & $\begin{array}{l}0.457 \\
{[3.28]^{* * *}}\end{array}$ \\
\hline Observations & 49 & 56 & 56 & 56 & 49 & 49 & 49 \\
\hline Number of countries & 5 & 5 & 5 & 5 & 5 & 5 & 5 \\
\hline
\end{tabular}

Notes: Robust $\mathrm{z}$ statistics are in brackets.

* significant at $10 \%$; ** significant at $5 \%$; ** significant at $1 \%$ 
Table 4 (concluded). Arellano-Bond Dynamic Panel Regressions

\begin{tabular}{|c|c|c|c|c|c|c|c|}
\hline \multirow[b]{2}{*}{ Financial liberalization } & \multicolumn{7}{|c|}{ Dependent Variable: Mean Log Deviations } \\
\hline & $\begin{array}{l}-0.242 \\
{[1.88]^{*}}\end{array}$ & & & & $\begin{array}{l}-0.307 \\
{[1.67]^{*}}\end{array}$ & $\begin{array}{l}-0.153 \\
{[0.76]}\end{array}$ & $\begin{array}{l}-0.473 \\
{[4.04]^{* * *}}\end{array}$ \\
\hline Private credit & & $\begin{array}{l}1.666 \\
{[3.05]^{* * *}}\end{array}$ & & & $\begin{array}{l}2.331 \\
{[2.80]^{* * *}}\end{array}$ & & \\
\hline Stock market capitalization & & & $\begin{array}{l}0.212 \\
{[0.73]}\end{array}$ & & & $\begin{array}{l}0.187 \\
{[0.54]}\end{array}$ & \\
\hline Stock market turnover & & & & $\begin{array}{l}-0.220 \\
{[0.98]}\end{array}$ & & & $\begin{array}{l}-0.344 \\
{[1.31]}\end{array}$ \\
\hline Cumulative inflation & $\begin{array}{l}-2.222 \\
{[0.58]}\end{array}$ & $\begin{array}{l}-2.054 \\
{[0.73]}\end{array}$ & $\begin{array}{l}-0.315 \\
{[0.10]}\end{array}$ & $\begin{array}{l}-1.913 \\
{[0.55]}\end{array}$ & $\begin{array}{l}-3.325 \\
{[1.50]}\end{array}$ & $\begin{array}{l}-1.305 \\
{[0.34]}\end{array}$ & $\begin{array}{l}-2.441 \\
{[0.69]}\end{array}$ \\
\hline Trade openness & $\begin{array}{l}-0.096 \\
{[0.12]}\end{array}$ & $\begin{array}{l}0.260 \\
{[0.43]}\end{array}$ & $\begin{array}{l}-0.489 \\
{[1.18]}\end{array}$ & $\begin{array}{l}-0.039 \\
{[0.04]}\end{array}$ & $\begin{array}{l}0.465 \\
{[0.81]}\end{array}$ & $\begin{array}{l}-0.328 \\
{[0.65]}\end{array}$ & $\begin{array}{l}0.337 \\
{[0.34]}\end{array}$ \\
\hline Lagged dependent variable & $\begin{array}{l}0.011 \\
{[0.09]}\end{array}$ & $\begin{array}{l}-0.038 \\
{[0.39]}\end{array}$ & $\begin{array}{l}0.053 \\
{[0.47]}\end{array}$ & $\begin{array}{l}0.020 \\
{[0.16]}\end{array}$ & $\begin{array}{l}-0.130 \\
{[1.16]}\end{array}$ & $\begin{array}{l}0.019 \\
{[0.14]}\end{array}$ & $\begin{array}{l}-0.002 \\
{[0.01]}\end{array}$ \\
\hline Observations & 49 & 56 & 56 & 56 & 49 & 49 & 49 \\
\hline Number of countries & 5 & 5 & 5 & 5 & 5 & 5 & 5 \\
\hline & \multicolumn{7}{|c|}{ Dependent Variable: Squared Coefficient of Variation } \\
\hline Financial liberalization & $\begin{array}{l}-0.248 \\
{[1.98]^{* *}}\end{array}$ & & & & $\begin{array}{l}-0.283 \\
{[2.20]^{* *}}\end{array}$ & $\begin{array}{l}-0.157 \\
{[1.34]}\end{array}$ & $\begin{array}{l}-0.381 \\
{[4.17]^{* * *}}\end{array}$ \\
\hline Private credit & & $\begin{array}{l}0.338 \\
{[1.23]}\end{array}$ & & & $\begin{array}{l}0.648 \\
{[1.46]}\end{array}$ & & \\
\hline Stock market capitalization & & & $\begin{array}{l}0.218 \\
{[1.86]^{*}}\end{array}$ & & & $\begin{array}{l}0.191 \\
{[1.46]}\end{array}$ & \\
\hline Stock market turnover & & & & $\begin{array}{l}-0.111 \\
{[1.38]}\end{array}$ & & & $\begin{array}{l}-0.195 \\
{[2.11]^{* *}}\end{array}$ \\
\hline Cumulative inflation & $\begin{array}{l}0.292 \\
{[0.20]}\end{array}$ & $\begin{array}{l}0.695 \\
{[0.66]}\end{array}$ & $\begin{array}{l}1.889 \\
{[1.67]^{*}}\end{array}$ & $\begin{array}{l}0.635 \\
{[0.56]}\end{array}$ & $\begin{array}{l}-0.428 \\
{[0.36]}\end{array}$ & $\begin{array}{l}1.155 \\
{[0.76]}\end{array}$ & $\begin{array}{l}0.120 \\
{[0.10]}\end{array}$ \\
\hline Trade openness & $\begin{array}{l}-0.399 \\
{[2.75]^{* * *}}\end{array}$ & $\begin{array}{l}-0.381 \\
{[2.43]^{* *}}\end{array}$ & $\begin{array}{l}-0.736 \\
{[2.51]^{* *}}\end{array}$ & $\begin{array}{l}-0.375 \\
{[1.55]}\end{array}$ & $\begin{array}{l}-0.285 \\
{[2.19]^{* *}}\end{array}$ & $\begin{array}{l}-0.638 \\
{[2.38]^{* *}}\end{array}$ & $\begin{array}{l}-0.160 \\
{[0.77]}\end{array}$ \\
\hline Lagged dependent variable & $\begin{array}{l}0.549 \\
{[5.37]^{* * *}}\end{array}$ & $\begin{array}{l}0.581 \\
{[19.24]^{* * *}}\end{array}$ & $\begin{array}{l}0.601 \\
{[12.95]^{* * *}}\end{array}$ & $\begin{array}{l}0.597 \\
{[10.38]^{* * *}}\end{array}$ & $\begin{array}{l}0.420 \\
{[4.72]^{* * *}}\end{array}$ & $\begin{array}{l}0.548 \\
{[6.72]^{* * *}}\end{array}$ & $\begin{array}{l}0.530 \\
{[5.79]^{* * *}}\end{array}$ \\
\hline Observations & 49 & 56 & 56 & 56 & 49 & 49 & 49 \\
\hline Number of countries & 5 & 5 & 5 & 5 & 5 & 5 & 5 \\
\hline
\end{tabular}

Notes: Robust $\mathrm{z}$ statistics are in brackets.

* significant at 10 percent; ** significant at 5 percent; *** significant at 1 percent.

\section{Other Robustness Checks}

In addition to the controls mentioned above, we conducted five more robustness checks, against which our main results held up.

The first robustness check we conducted was to drop one country at a time, in order to investigate whether a single country was driving the results. This could have been the case since the sample contains only five countries, and Figures 1 and 2 seem to indicate that effects of 
financial liberalization were stronger in some countries than in others. We found, however, that our results held up in all cases.

As a second robustness check, we included a crisis dummy variable in our regressions. The effect of a currency or banking crisis on allocative efficiency is unclear. On the one hand, disruptions associated with crises, such as credit crunches and high inflation, may impair the functioning of the financial sector and reduce allocative efficiency. On the other hand, crises may result from the gradual buildup of imbalances, such as an overvalued exchange rate or an asset price bubble, and these imbalances may result in a misallocation of resources. To the extent that the crisis corrects these imbalances, it may improve allocative efficiency. The crisis dummy was set equal to one if the country experienced a currency crisis or banking crisis, based on the crisis database of Bordo and others (2000). The coefficient on the crisis dummy was found to be positive, suggesting that crises widen the variation in returns. However, it was almost always insignificant, and it did not change any of our main results.

Third, we ran our regressions using only one of the six the subcomponents of the financial liberalization index, rather than the aggregate index. We found that doing so did not change the main result, and that no single component was as robust as the aggregate index itself. However, it should be noted that the liberalization subcomponents are substantially correlated, so including only one subcomponent at a time may not necessarily be informative in terms of identifying whether it was that specific aspect of liberalization that mattered.

Fourth, we explored interactions between financial liberalization and financial deepening, to allow for the possibility of nonlinear effects. In particular, we wanted to test whether it requires both financial liberalization and financial deepening to realize a significant improvement in allocative efficiency. Including these interactions, however, did not produce any interesting new results.

Finally, we tried interacting the financial liberalization index with country dummies, i.e., allowing the coefficient on financial liberalization to vary across countries, but this did not generate any interesting patterns either. The financial liberalization coefficient for India (which we used as the uninteracted coefficient) was negative but insignificant; the coefficient for Jordan was significantly more negative than for India; the coefficients for Korea and Malaysia were insignificantly more negative than for India; and the coefficient for Thailand was significantly more positive than for India. ${ }^{29}$

\section{CONCLUSION}

Although recent studies have found little or no effect of liberalization on the level of savings and investment, the primary finding of this paper is that liberalization does improve allocative efficiency. We thus suggest that the benefits of liberalization are primarily through its effect on the quality, not the quantity, of investment.

${ }^{29}$ Note that these estimations are quite fragile, as each country coefficient is estimated using only 11 or 12 observations. 
With a simple model, we predicted that financial liberalization, by equalizing access to credit, reduces the variation in expected returns across firms, which we measured by the dispersion in Tobin's Q. We then tested this prediction and found that financial liberalization is strongly negatively associated with the dispersion in Q and, hence, positively associated with allocative efficiency.

The positive effect of financial liberalization on allocative efficiency is surprisingly robust. As our panel regression results showed, it holds up after controlling for several, possibly related, omitted variables, including inflation, trade openness, private credit growth, and stock market turnover. It also holds up after taking into account persistence, endogeneity, and other factors. This robustness is remarkable, given the limited amount of data available and given the bias against finding a positive impact owing to the focus on large, publicly listed firms and the use of an unbalanced sample.

Three additional findings are worth noting. First, we found that it is financial liberalization, rather than financial deepening, that matters for allocative efficiency. When the liberalization index was included alongside financial-deepening measures, standard financial-deepening indicators, such as bank credit and stock market capitalization, were insignificant or wrongly signed. In fact, increasing bank credit often led to a worsening of allocative efficiency, which might reflect misallocation of credit during lending booms. Second, we found that stock market turnover did have an independent and positive effect on efficiency. This may reflect better credit allocation when stock markets are liquid, or it may simply result from better valuation, since stock prices in more developed stock markets are more accurate measures of companies' intrinsic values. A final observation is that the dispersion in firms' marginal returns often seems to increase prior to liberalization, indicating a steady worsening of allocative efficiency during periods of financial repression. This might be explained by a prolonged channeling of credit to selected sectors or firms and a consistent denial of credit to other sectors or firms. Further research would be needed to ascertain whether these conjectures are correct or whether alternative mechanisms are at work. 


\section{Measuring Dispersion in Q: Four Inequality Indices}

The first, and most well-known inequality index we use is the Gini coefficient, which is defined as

$$
G I N I=\frac{1}{2 n^{2} \mu} \sum_{i=1}^{n} \sum_{j=1}^{n}\left|\hat{q}_{i}-\hat{q}_{j}\right|,
$$

where $\mu$ denotes the mean of $\hat{q}_{i}$ among all $n$ firms in a given country. Note that the Gini takes differences over all pairs of firms, $i$ and $j$, as opposed to differences vis-à-vis the mean of the distribution, like the standard deviation or variance would do.

The other three measures of dispersion are all derived from the following generalized entropy (probabilistic) class of inequality indices: ${ }^{30}$

$$
E(\alpha)=\frac{1}{\alpha^{2}-\alpha}\left[\frac{1}{n} \sum_{i=1}^{n}\left(\frac{\hat{q}_{i}}{\mu}\right)^{\alpha}-1\right],
$$

where $\alpha \geq 0$.

This general formula for the parametric class of inequality indices has a number of desirable properties, including symmetry, population replication, decomposability, as well as scale invariance.

One commonly used inequality index that can be derived from this generalized entropy class is the mean log deviation:

$$
E(0)=\frac{1}{n} \sum_{i=1}^{n} \log \left(\frac{\mu}{\hat{q}_{i}}\right)
$$

Another well-known inequality index that is a special case of the entropy class is the Theil index:

$$
E(1)=\frac{1}{n} \sum_{i=1}^{n} \frac{\hat{q}_{i}}{\mu} \log \left(\frac{\hat{q}_{i}}{\mu}\right) .
$$

The final inequality index we compute is half the square of the coefficient of variation:

$$
E(2)=\frac{1}{2 n \mu^{2}} \sum_{i=1}^{n}\left(\hat{q}_{i}-\mu\right)^{2}
$$

${ }^{30}$ See Cowell (1995) and Deaton (1997). 


\section{Table 5. Coding of Financial Reforms in the Five Countries}

\section{INDIA}

Credit Controls/Reserve Requirements

Cash and statutory reserve requirements remain high, and more than 40 percent of lending is still directed toward "priority sectors". Rates on small loans are still provided at lower-than-market rates. 0 throughout sample.

\section{Interest Rates}

Lending and deposit rates were regulated beginning in 1962 and 1964, respectively. In October 1988 the lending rate ceiling was converted to a floor, which was eliminated in October 1994. Term deposit rates were liberalized subjet to a ceiling in 1992, and were completely freed between 1995-97. Controls remain on small loans (25 percent of total lending), on savings/postal deposits, and non-resident FX deposits. 0 from 1973-87, 1 from 1988 91, 2 in 1992.

Entry Barriers

Entry of private banks was deregulated in January 1993, resulting in the licensing of nine new domestic and twenty-two new foreign banks. Joint Indian-foreign ventures are allowed, but foreign banks can own only up to 20 percent of equity. Some restrictions on foreign bank branching remain. 2 from 1993 onwards.

Regulations

Narasimham Committtee recommendations on prudential norms and standards are phased in from 1993-96. The regulatory framework was strengthened signficantly in 1992. 1 from 1992, 2 from 1993 onwards.

\section{Privatization}

Bank nationalization took place in 1969. The banking sector is still dominated by state-owned banks, which hold some 80 percent of total assets. 0 throughout sample.

International Transactions

Liberalization began with the easing of some restrictions on portfolio and direct investment in 1991-1993. In 1993 the exchange rate system was unified. Most remaining restrictions on current account transactions were eliminated in 1994, culminating in India's formal acceptance of the IMF's Article VIII. Foreign exchange regulations are still significant, as are restrictions on the short-term flows. 1 in 1991, 2 from 1994 onwards.

\section{JORDAN}

Credit Controls/Reserve Requirements

Privileges of specialized credit institutions are gradually phased out beginning in 1996; preferential credit facilities remain for agricultural, handicrafts and export sectors. 0 from 1973-1995, 1 from 1996.

Interest Rates

Interest rates are liberalized in 1988. 2 from 1988.

Entry Barriers

In 1984, a decree limiting foreign participation in banking to 49 percent is rescinded. Legislation from 1997 onwards has eased the entry of a variety of financial products. 1 from 1984-96, 2 from 1997.

Regulations

Prudential regulations are improved in 1988; risk-weighted capital adequacy requirement raised to $12 \%$ effective June 1997. 0 from 1973-1983, 1 from 1984-1996, 2 from 1997.

Privatization

State ownership of banks is virtually absent in Jordan. 3 throughout sample. International Transactions

The IMF's Article VIII is accepted February 1995. 1 from 1973-1994, 2 from 1995. 
Table 5. Coding of Financial Reforms in the Five Countries (continued)

\section{KOREA}

Credit Controls/Reserve Requirements

In 1982 credit ceilings and preferential interest rates are abolished. The use of credit and management directives is reduced between 1982-1988. Reserve requirements are lowered to 5.5\% in 1981, from more than $20 \%$ before 1980. 1 in 1981, 2 from 1982.

Interest Rates

In 1984, interbank call rates and corporate bond rates are freed; interest rate ranges for other instruments are introduced. Interest rate control is reintroduced between 1989-90. Interest rate liberalization is resumed in 1991, and implemented from 1991-95. 0 from 1973-1983, 1 from 1984-1988, 0 from 1989-1990, 2 from 1991.

Entry Barriers

In 1981, restrictions on bank entry and banking activities are eased; non-bank financial institutions are allowed, and limited joint ventures are permitted. In 1986, bank branching for domestic financial institutions is liberalized.

1 from 1981-85, 2 from 1986.

Regulations

Reform of supervisory procedures is gradually implemented between 1982-1988; regulatory and support measures for the stock exchange implemented between 1989-1992. Commercial banks are required to achieve $8 \%$ capital adequacy ratios in 1995. 1 from 1982-1994, 2 from 1995.

Privatization

As of 1980 , state ownership in the banking sector was about $25 \%$. The government privatized five nationwide commercial banks between 1981-83. Government ownership increases to $60 \%$ of the banking sector between 1997-99. 1 from 1973-90, 2 from 1981.

International Transactions

Controls on outward and inward foreign investment gradually eased between 1985-1996. The IMF's Article VIII is accepted October 1988. 1 from 1985, 2 from 1988.

\section{MALAYSIA}

Credit Controls/Reserve Requirements

In 1976 the net lending requirement for priority sectors is reduced to 20 percent, from 50 percent the previous year. In 1980 the scope of priority lending is reduced, and subsidized credit is eliminated gradually. 1 from 197679, 2 from 1980.

Interest Rates

Interest rates are liberalized in October 1978; controls are reimposed between October 1985 and January 1987 in response to recession, then liberalized again between 1987-1991. 3 from 1978-84, 1 from 1985-86, 3 from 1987.

Entry Barriers

In 1985 finance companies are allowed to participate in interbank market; merchant banks are allowed to issue nonnegotiable CDs. 1 from 1985.

Regulations

A uniform risk-based capital adequacy framework is adopted in 1989. Additional reforms promote active secondary markets in government securities, and strengthen supervisory functions. 1 from 1973-88, 2 from 1989.

\section{Privatization}

The banking sector is privatized gradually from 1989 onwards, reducing state ownership in the banking sector from more than $50 \%$ in 1985 to $0 \%$ by 2000.1 in 1989,2 in 1995,3 in 2000. 
Table 5. Coding of Financial Reforms in the Five Countries (concluded)

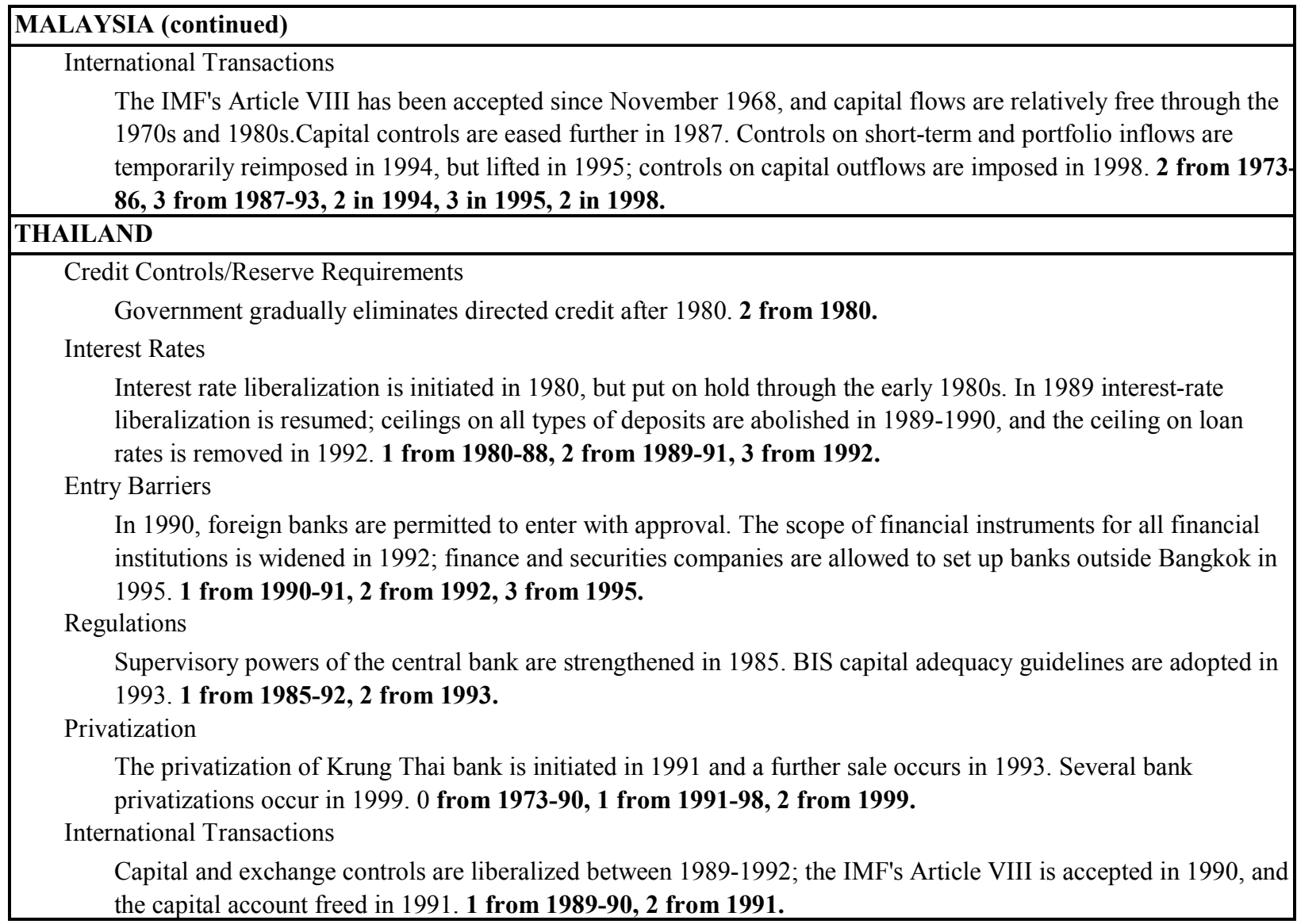




\section{REFERENCES}

Abiad, Abdul, and Ashoka Mody, 2003, "Financial Reform: What Shakes It? What Shapes It?," IMF Working Paper 03/70 (Washington: International Monetary Fund); forthcoming, American Economic Review.

Acemoglu, Daron, and Zilibotti, 1997, "Does Prometheus Unbound by Chance? Risk, Diversification, and Growth," Journal of Political Economy, Vol. 105, No. 4, pp. 709-51.

Bandiera, Oriana, Gerard Caprio, Patrick Hanohan, and Fabio Schiantarelli, 2000, "Does Financial Reform Raise or Reduce Saving?," Review of Economics and Statistics, Vol. 82, No. 2 (May), pp. 239-63.

Beck, Thorsten, Ross Levine, and Norman Loayza, 2000, "Finance and the Sources of Growth," Journal of Financial Economics, 58 (October), pp. 261-300.

Bekaert, Geert, and Campbell R. Harvey, 2000, "Foreign Speculators and Emerging Equity Markets,” Journal of Finance, Vol. 55, pp. 565-614.

Blanchard, Olivier, C. Rhee, and Lawrence Summers, 1993, "The Stock Market, Profit, and Investment," Quarterly Journal of Economics, Vol. 108, No. 1, pp. 115-36.

Bond, Stephen and Jason Cummins, 2001, "Noisy Share Prices and the Q Model of Investment," Institute of Fiscal Studies Working Paper 01/22.

Booth, Laurence, Varouj Aivazian, Aslí Demirgüc-Kunt, and Vojislav Maksimovic, 2001, "Capital Structures in Developing Countries," Journal of Finance, Vol. 56, pp. $87-130$.

Bordo, Michael D., Barry Eichengreen, Daniela Klingebiel, and Maria Soledad Martinez Peria, 2000, "Financial Crises: Lessons from the Last 120 Years," Economic Policy: A European Forum, No. 32 (April), pp. 51-82.

Chari, Anusha, and Peter Blair Henry, 2003, “The Invisible Hand in Emerging Markets: Discerning or Indiscriminate?," Working Paper, University of Michigan Business School. Available via the Internet at: http://webuser.bus.umich.edu/achari/achari.htm.

Cho, Yoon Je, 1988, "The Effect of Financial Liberalization on the Efficiency of Credit Allocation," Journal of Development Economics, Vol. 29, pp.101-10.

Cowell, Frank, 1995, Measuring Inequality (Englewoods Cliffs, New Jersey: Prentice-Hall, 2nd ed.). 
Deaton, Angus, 1997, The Analysis of Household Surveys: A Microeconometric Approach to Development Policy (Baltimore: Johns Hopkins University Press).

Demirgüc-Kunt, Aslí, and Enrica Detragiache, 2001, "Financial Liberalization and Financial Fragility," in Financial Liberalization: How Far, How Fast? ed. by Gerard Caprio, Patrick Honohan and Joseph E. Stiglitz (New York: Cambridge University Press).

Devereux, Michael B., and Gregor W. Smith, "International Risk Sharing and Economic Growth," International Economic Review, Vol. 53, No. 2, pp. 363-84.

Edison, Hali, and Francis Warnock, 2003, "A Simple Measure of the Intensity of Capital Controls," Journal of Empirical Finance, Vol. 10, No. 1-2 (February), pp. 81-03.

Galindo, Arturo, Fabio Schiantarelli, and Andrew Weiss, 2002, "Does Financial Liberalization Improve the Allocation of Investment?: Micro Evidence From Developing Countries," IADB Research Department Working Paper No. 467 (Washington: Inter-American Development Bank).

Hayashi, Fumio, 1982 “Tobin's Marginal Q and Average Q: A Neoclassical Interpretation,” Econometrica, Vol. 50, No. 1, pp. 213-24.

Hellmann, Thomas, Kevin Murdock, and Joseph Stiglitz, 1996, "Financial Restraint," Chapter 6, The Role of Government in East Asian Economic Development, edited by Masahiko Aoki, Hyung-Ki Kim, and Masahiro Okuno-Fujiwara (New York: Oxford University Press).

Ito, Motoshige, Masahiro Okuno, Kazuharu Kiyono, and Kotaro Suzumura, 1998, Sangyo Seisaku no Keizai Bunseki, Tokyo Daigaku Shuppankai (Tokyo: University of Tokyo Press).

Jayaratne, Jith, and Philip E. Strahan, 1996, “The Finance-Growth Nexus: Evidence from Bank Branch Deregulation," Quarterly Journal of Economics, Vol. 111, No. 3, pp. 639-70.

Kaminsky, Graciela, and Sergio Schmukler, 2003, "Short-Run Pain, Long-Run Gain: The Effects of Financial Liberalization," IMF Working Paper 03/34 (Washington: International Monetary Fund).

King, Robert G., and Ross Levine, 1993, "Finance and Growth: Schumpeter Might Be Right," Quarterly Journal of Economics, Vol. 108, No. 3, pp. 717-37.

Love, Inessa, 2001, Financial Development and Financing Constraints: International Evidence from the Structural Investment Model, World Bank (Washington: World Bank) 
McKinnon, Ronald, 1973, Money and Capital in Economic Development (Washington: Brookings Institution).

Morck, Randall, Bernard Yeung, and Wayne Yu, 2000, “The Information Content of Stock Markets: Why Do Emerging Markets Have Synchronous Stock Price Movements?” Journal of Financial Economics, Vol. 58, No. 1-2, pp. 215-60.

Obstfeld, Maurice, 1994, "Risk-Taking, Global Diversification, and Growth," American Economic Review, Vol. 84, No. 5, pp. 1310-29.

Phelan, Christopher, "Repeated Moral Hazard and One-Sided Commitment," Journal of Economic Theory, Vol. 66, No. 2, pp. 488-506.

Rajan, Raghuram, and Luigi Zingales, 1998, "Financial Dependence and Growth," American Economic Review, Vol. 88, No. 3, pp. 559-86.

Sancak, Cemile, 2002, Financial Liberalization and Real Investment: Evidence from Turkish Firms, IMF Working Paper 02/100, June (Washington: International Monetary Fund)

Shaw, Edward S., 1973, Financial Deepening in Economic Development (New York: Oxford University Press).

Singh, Ajit, and Javid Hamid, in collaboration with Bahram Salimi and Yoichi Nakano, 1992, Corporate Financial Structures in Developing Countries, IFC Technical Paper 1 (Washington, DC: International Finance Corporation). Available via the Internet at http://www.ifc.org/economics/pubs/techpap1/tp1.pdf

Townsend, Robert M, and Kenichi Ueda, 2003, "Financial Deepening, Inequality, and Growth: A Model-Based Quantitative Evaluation," IMF Working Paper 03/193 (Washington: International Monetary Fund).

Ueda, Kenichi, 2000, Increasing Returns, Long-run Growth, and Financial Intermediation, Ph.D. Dissertation (University of Chicago).

Wurgler, Jeffrey, 2000, Financial Markets and the Allocation of Capital, Journal of Financial Economics, Vol. 58, pp. 187-214. 